\title{
Working
}

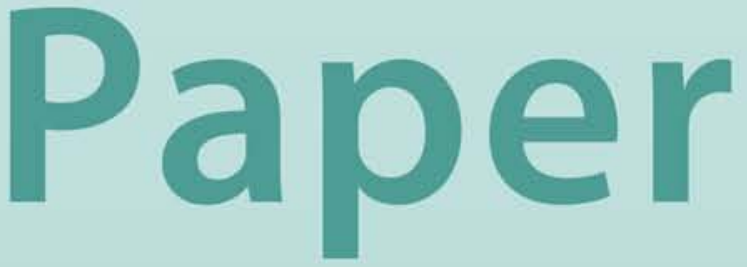


The Effects of Economic News on Commodity Prices:

Is Gold Just Another Commodity?

Shaun K. Roache and Marco Rossi 
(C) 2008 International Monetary Fund

$\mathrm{WP} / 09 / 140$

\title{
IMF Working Paper
}

Research Department

\section{The Effects of Economic News on Commodity Prices: Is Gold Just Another Commodity?}

\section{Prepared by Shaun K. Roache and Marco Rossi ${ }^{1}$}

Authorized for distribution by Thomas Helbling

July 2009

\begin{abstract}
This Working Paper should not be reported as representing the views of the IMF. The views expressed in this Working Paper are those of the author(s) and do not necessarily represent those of the IMF or IMF policy. Working Papers describe research in progress by the author(s) and are published to elicit comments and to further debate.

The paper uses an event study methodology to investigate which and how macroeconomic announcements affect commodity prices. Results show that gold is unique among commodities, with prices reacting to specific scheduled announcements in the United States and the Euro area (such as indicators of activity or interest rate decisions) in a manner consistent with gold's traditional role as a safe-haven and store of value. Other commodity prices, where such news is significant, exhibit pro-cyclical sensitivities and these have risen somewhat as commodities have become increasingly financialized. These results are important for those trading in the commodity markets on a frequent basis and long-term market participants that take their decisions based on information on price fundamentals, which are reflected in the release of macroeconomic announcements.

JEL Classification Numbers: G12, G13, G14, F31

Keywords: Macroeconomic news, gold, volatility, exchange rates

Author’s E-Mail Address: sroache@imf.org, mrossi@imf.org

\footnotetext{
${ }^{1}$ Excellent research assistance from Richard LaRock, formerly at the IMF, is greatly appreciated. We would like to thank Andy Berg, Kevin Cheng, Thomas Helbling, Ydahlia Metzgen, Roberto Perrelli, David Romer, and seminar participants from the Finance and Research departments for helpful comments and suggestions. The usual disclaimer applies.
} 


\section{Table of contents}

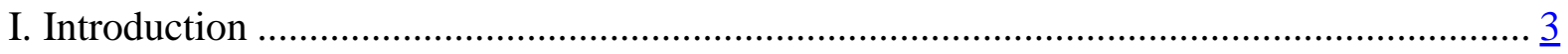

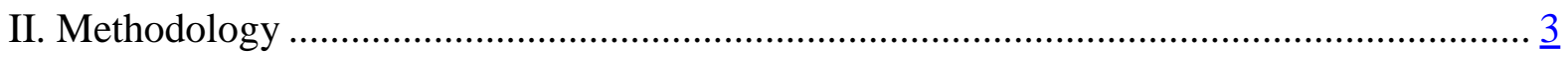

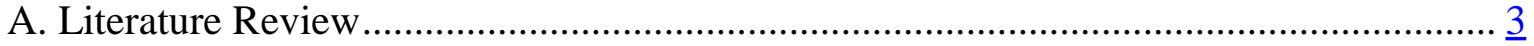

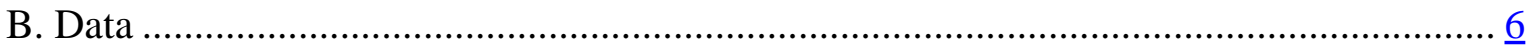

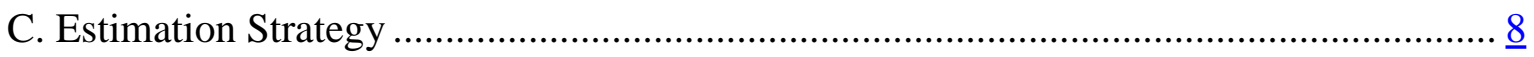

III. Results............................................................................................................ 11

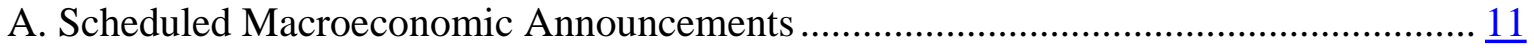

B. “Good News”, "Bad News”, and Volatility .......................................................... 15

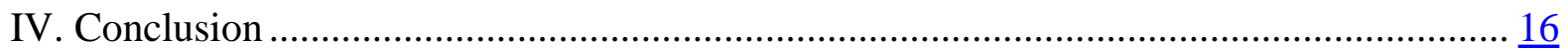

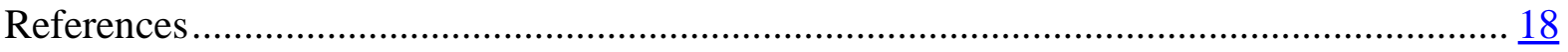

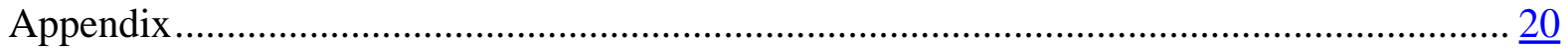




\section{INTRODUCTION}

Commodity prices have not been immune to the recent protracted period of financial turmoil. For some commodities, the pro-cyclical nature of demand has driven price moves, while for gold, the crisis has underscored its role as a safe-haven asset and store of value. Insights on how commodity and gold prices move and react to news, particularly in this context of higher volatility, can shed light on the macroeconomic factors that drive short-term price patterns. This is useful for those trading in these markets on a frequent basis and also for long-term market participants that take their decisions based on price fundamentals, which may be reflected in the release of macroeconomic information.

Using an event study methodology that has been used successfully for asset prices, this paper investigates which and how relevant macroeconomic announcements affect commodity prices. Our focus is on scheduled and periodic (rather than ad hoc) macroeconomic data releases. The fact that the timing of such announcements is known in advance makes the release of potentially price-sensitive information a potentially key factor that traders may wish to consider when effecting transactions. Reflecting its special role in the international financial system, we contrast the behavior of gold and we find that it behaves very differently to other commodities. Gold prices react to specific scheduled announcements in the United States and the Euro area (such as indicators of activity or interest rate decisions) in a manner consistent with its traditional role as a safe-haven and store of value. In contrast, other commodity prices, where such news is significant, exhibit pro-cyclical sensitivities, albeit much less than financial assets.

The paper is organized as follows. Section II reviews the literature, the data, and presents the methodology. Section III reports and discusses the results, while Section IV concludes.

\section{Methodology}

\section{A. Literature Review}

\section{Asset prices and macroeconomic announcements}

Previous literature on the impact of macroeconomic announcements has mostly focused on bond and currency markets, with fairly clear evidence that macroeconomic news has significant price and volatility effects. Rossi (1998) finds that certain key economic announcements cause U.K government bond yield changes of between 2-6 basis points, including beyond the trading day. Fleming and Remelona (1999) find that the arrival of public information has a large effect on prices and subsequent trading activity, particularly during periods in which uncertainty (as measured by implied volatility) is high. Balduzzi, Elton, and Green (2001) indicate that a wide variety of economic announcements affect U.S. Treasury bond prices, with labor market, inflation, and durable goods orders data having the largest impact. 
Commodities are not financial assets, but these results are relevant for our study given the relationship between commodity prices and some financial asset valuations. Frankel (2008) argues that interest rates can have a significant effect on commodity prices and Roache (2008) provides supporting empirical evidence. The strongest and most consistent relationship, however, is between the U.S. dollar and commodity prices, and there is a building consensus that macroeconomic news does affect exchange rates.

Andersen et al (2002) explore the relationship between macroeconomic news and the U.S. dollar exchange rate against six major currencies. They confirm macroeconomic news generally has a statistically significant correlation with intra-day movements of the U.S. dollar, with "bad" news - for example, data indicating weaker-than-expected growthhaving a larger impact than "good" news. Galati and Ho (2003) found similar results using daily data. Ehrmann and Fratzscher (2005) focused on the euro-dollar exchange rate and found that U.S. news tended to have more of an effect on the exchange rate than German news. Activity indicators such as GDP and labor market data had a particularly large and significant effect, with the news impact increasing during times of high market uncertainty.

\section{A focus on commodities and gold}

Common themes have emerged from the literature focused on commodities and announcements (Table 1). The number and significance of macroeconomic announcements on commodity prices is lower than that for U.S. Treasury bonds, exchange rates, and equity markets. However, a number of key U.S. indicators, including inflation, GDP, and employment statistics, repeatedly show the ability to move some commodity prices; in general, energy products have tended to be less sensitive, while gold has been most sensitive.

In general, earlier studies, summarized in Table 1, based on sample periods in the 1980s and 1990s confirm the conventional wisdom that gold is a hedge against higher inflation and economic uncertainty. For example, gold prices tend to rise if U.S. inflation and output unexpectedly increase, or if the labor market tightens by more than the market projects (Ghura (1990) and Christie-David, Chaudry and Koch (2000)).

Gold also appears sensitive to news related to supply and demand. In particular, some studies indicate that central bank announcements regarding sales of gold reserves have tended to cause price declines - see Cai, Cheung, and Wong (2001). Other studies have found that gold's sensitivity to news varies through time, with Hess, Huang, and Niessen (2008) presenting evidence that it is dependent upon the state of the economy, with sensitivity increasing during recessions. 
Table 1. Studies of Gold and the Impact of Macroeconomic Announcements

\begin{tabular}{|c|c|c|}
\hline Study & Data and Method & Results \\
\hline $\begin{array}{l}\text { Frankel } \\
\text { and } \\
\text { Hardouveli } \\
\text { s (1985) }\end{array}$ & $\begin{array}{l}\text { Daily reactions of nine } \\
\text { commodities to U.S. money } \\
\text { supply announcements } \\
\text { from } 1980-1982 \text {. }\end{array}$ & $\begin{array}{l}\text { - Gold and other commodities negatively related. } \\
1 \text { percentage point positive shock in the money supply } \\
\text { leads to a } 0.7 \text { percent decline in gold. } \\
\text { - Authors contend that these results indicate that the } \\
\text { market, following a positive money supply surprise, } \\
\text { anticipate quick Fed action that would lead to a } \\
\text { tightening in policy. }\end{array}$ \\
\hline $\begin{array}{l}\text { Barnhart } \\
\text { (1989) }\end{array}$ & $\begin{array}{l}\text { Sensitivity of } 15 \text { commodity } \\
\text { futures prices on the } \\
\text { surprise component of } \\
\text { announcements for } 12 \text { U.S. } \\
\text { economic variables. OLS } \\
\text { single equation and SUR } \\
\text { system estimations using } \\
\text { daily data from 1980-1984. }\end{array}$ & $\begin{array}{l}\text { Rejects hypothesis that all parameters are equal to } \\
\text { zero for just four commodities, including gold. } \\
\text { Just two announcements were significant for the gold } \\
\text { price: the M1 money aggregate with a negative } \\
\text { coefficient; and the Federal Reserve surcharge rate } \\
\text { indicating that a surprise } 100 \text { basis point increase in } \\
\text { the rate would lead to a fall in the gold price of nearly } \\
1 \text { percent. } \\
\text { Similar results obtained from estimates for the metals } \\
\text { sub-group-including gold, silver, and copper-with } \\
\text { Fed Discount Rate announcements also significant. }\end{array}$ \\
\hline $\begin{array}{l}\text { Ghura } \\
\text { (1990) }\end{array}$ & $\begin{array}{l}\text { Regression of daily } \\
\text { commodities futures price } \\
\text { on } 14 \text { U.S. macroeconomic } \\
\text { announcements from 1985- } \\
89 \text {, with an unspecified } \\
\text { correction for } \\
\text { heteroscedasticity. }\end{array}$ & $\begin{array}{l}\text { - Gold sensitive only to employment reports, with } \\
\text { positive surprise leading to higher price; no significant } \\
\text { effect from inflation or activity. } \\
\text { - Results may be biased lower by inclusion of other } \\
\text { financial variables (e.g. exchange rates) as } \\
\text { regressors. }\end{array}$ \\
\hline $\begin{array}{l}\text { Christie- } \\
\text { David, } \\
\text { Chaudhry, } \\
\text { and Koch } \\
(2000)\end{array}$ & $\begin{array}{l}\text { Sensitivity of gold and silver } \\
\text { futures prices over } 15 \\
\text { minute intervals to } 23 \text { U.S. } \\
\text { macroeconomic news } \\
\text { announcements from } 1992- \\
\text { 1995. OLS estimations. }\end{array}$ & $\begin{array}{l}\text { - Formal variance tests show gold and silver price } \\
\text { volatility is higher during days in which there are } \\
\text { announcements. } \\
\text { - Metals prices are sensitive to a fewer number of } \\
\text { announcements than bond futures. } \\
\text { - GDP, inflation, and capacity utilization are all } \\
\text { significant, with the expected positive sign. }\end{array}$ \\
\hline $\begin{array}{l}\text { Cai, } \\
\text { Cheung, } \\
\text { and Wong } \\
\text { (2001) }\end{array}$ & $\begin{array}{l}\text { Regression of } 5 \text { minute } \\
\text { gold futures prices on } 23 \\
\text { U.S. macroeconomic } \\
\text { announcements over 1994- } \\
\text { 97. Two-step estimation } \\
\text { using GARCH and a } \\
\text { flexible Fourier form to } \\
\text { capture smooth intraday } \\
\text { patterns. }\end{array}$ & $\begin{array}{l}\text { - Clear evidence of GARCH effects in intraday prices. } \\
\text { - Six of the largest } 25 \text { absolute returns associated with } \\
\text { central banks' selling of gold reserves. } \\
\text { - } \text { Number and significance of announcements lower for } \\
\text { gold than for bonds or currencies. } \\
\text { Coefficients on most announcements had the correct } \\
\text { sign, with three statistically significant: employment } \\
\text { reports, inflation, and GDP. }\end{array}$ \\
\hline
\end{tabular}




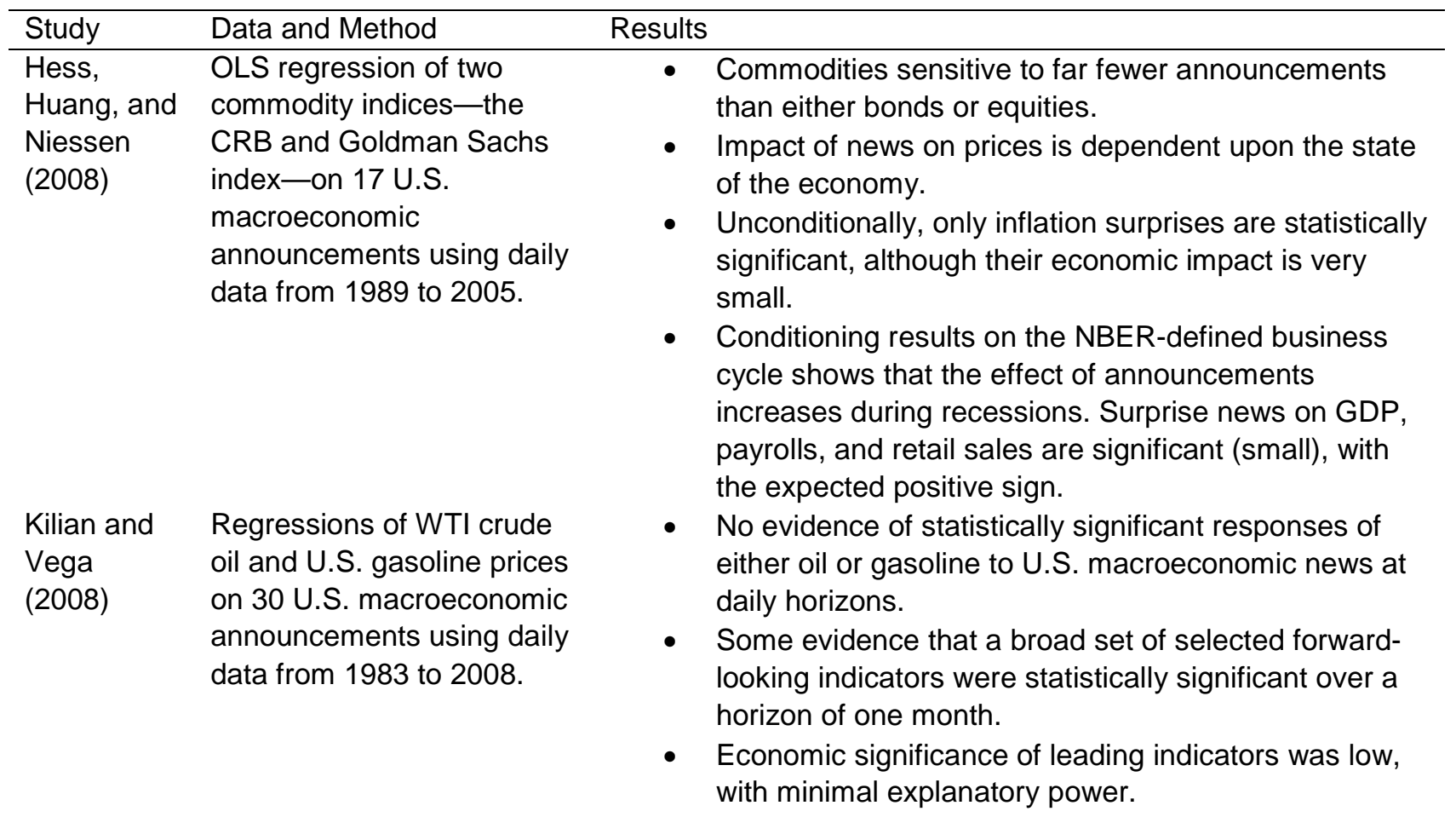

Source: Authors.

\section{B. Data}

\section{Commodity prices}

We use daily price data for 12 commodity futures contracts that have available price data over the period from January 1997 to June 2009. We have included precious metals, base metals, energy, and agricultural commodities (see Appendix Table A1 for details). Futures prices are taken from the nearest contract often used as the benchmark for that commodity and traded on exchanges in the United States.

We focus on the futures market, rather than the spot market, for two reasons. First, the spot market for some commodities, including certain precious and base metals, is dominated by trading in London, which means that official fixing prices have less time to respond to daily developments in the United States due to the five hour time difference. ${ }^{2}$ Second, spot prices are often positively correlated with the future with a one-day lag, which indicates that the impact of U.S. announcements on the futures price is likely to affect the spot price the

\footnotetext{
${ }^{2}$ For example, the London Bullion Market Association's “fixing price” is determined by an open process at which market participants can transact business on the basis of a single quoted price, which is adjusted until the market clears. The fixing is conducted twice a day at 10:00am and 3:00pm London time.
} 
following day (see the example for gold in Table 2). This is consistent with previous research indicating that commodities futures markets lead developments in spot markets (e.g. Antoniou and Foster (1992) and Yang, Balyeat, and Leatham (2005)).

Table 2. Gold Futures and Spot Prices—Correlation Matrix 1/

\begin{tabular}{lrrrrrrrr}
\hline & \multicolumn{3}{c}{ Same day } & & \multicolumn{3}{c}{ Previous day } \\
\cline { 2 - 3 } \cline { 6 - 8 } & $\begin{array}{c}\text { Gold } \\
\text { future }\end{array}$ & Gold spot & U.S. dollar & & \multicolumn{1}{c}{ Gold } \\
future & Gold spot & U.S. dollar \\
\hline Gold future & 1.00 & $\mathbf{0 . 2 6}$ & $\mathbf{- 0 . 4 4}$ & & 0.00 & 0.02 & -0.02 \\
Gold spot & $\mathbf{0 . 2 6}$ & 1.00 & $\mathbf{- 0 . 1 9}$ & & $\mathbf{0 . 7 2}$ & $-\mathbf{0 . 0 6}$ & $\mathbf{- 0 . 3 1}$ \\
U.S. dollar & $\mathbf{0 . 4 4}$ & $\mathbf{- 0 . 1 9}$ & 1.00 & & -0.03 & 0.01 & -0.01 \\
\hline
\end{tabular}

Source: Authors' estimates.

1/ Correlation coefficients in bold are significant at the 5 percent level.

While many recent announcement studies use intraday data, we use daily data, finding the arguments of Erhmann and Fratzscher (2005) in support of daily frequencies to be convincing. They note that Payne (2003) provides evidence of liquidity effects causing trades during the minutes following a news event that are not necessarily a response to the fundamental content of that news - e.g. trades based on participants covering a short position to reduce risk. Also, it may take longer than a few minutes for markets to absorb the significance of news events. For many commodities, which are often perceived to react to the response of other financial variables such as exchange rates (see below), this may be particularly relevant.

The main objection to daily data - that it is noisy and polluted with many other market events-is a minor concern if we make the reasonable assumption, based on efficient market assumptions, that non-announcement shocks on the release dates of specific reports are white noise and unbiased.

\section{Macroeconomic announcements}

Commodity prices, in common with financial assets, incorporate expectations regarding the future. As a result, the impact of news announcements should focus on the surprise component of the news. A popular technique, which we use here, is to measure the surprise by the distance between the actual outturn $X_{t}$ and the publicly-observable consensus estimate $E_{t-1}\left(X_{t}\right)$, scaled by the sample estimate of the variation in the announcements $\sigma_{X}$. The surprises may be interpreted as standard deviations from the consensus: 
$Z_{i t}=\frac{X_{i t}-E_{t-1}\left(X_{i t}\right)}{\sigma_{X}}$

We use the analyst consensus estimates published by Bloomberg for each announcement and select a set of 13 monthly or quarterly U.S. macroeconomic announcements from those included by Ehrmann and Fratscher (2005), with some substitutions, including the Employment Cost Index and Existing Home Sales (see Table A1). We focus mainly on announcements about U.S. macroeconomic developments since these have been shown to have the greatest influence on variables such as the U.S. dollar. However, we also include ECB and Bank of England interest rate decisions and the German IFO business climate survey; the IFO indicator was the only Euro area indicator shown to influence the U.S. dollar-Euro exchange rate in Ehrmann and Fratscher (2005). Commodities are traded globally and news from other emerging economies, particularly China given the growth in its demand across a wide range of products, may also influence prices. For now, the number of observations available to assess formally the impact of Chinese macroeconomic announcements is limited, which makes us cautious about their inclusion. However, this clearly remains a fertile area for future research.

\section{Estimation Strategy}

\section{The problem with ordinary least squares (OLS)}

The simplest way to assess the significance of specific announcements is by estimating regressions in which the log change in the futures price $\Delta p$ is the dependent variable, $J$ surprise elements of the news announcements $Z_{i}$ including $K-1$ lags, and $L$ lags of the price return are the exogenous variables, and $\varepsilon$ is the unexplained portion of the price return:

$$
\begin{aligned}
& \Delta p_{t}=\alpha+\sum_{j=1}^{J} \sum_{k=0}^{K} \beta_{j k} Z_{j t-k}+\sum_{l=1}^{L} \lambda_{l} \Delta p_{t-l}+\varepsilon_{t} \\
& \varepsilon_{t} \sim(0, \sigma)
\end{aligned}
$$

This may be estimated using OLS, but the most obvious objection to this approach is that the price return variance of many commodity futures exhibit periods of high and low volatility, or heteroscedasticity. This violates the assumptions of OLS and leads to inefficient estimators. We find very strong evidence for commodity price volatility time-variation and clustering (see Appendix Figures A1 and A2). 


\section{A GARCH approach}

When asset return volatilities exhibit time-variation and clustering, a GARCH specification, which jointly models price returns and volatility, is often appropriate. ${ }^{3}$ In this model, the conditional variance of asset price returns $h_{t}$ is assumed to be a function of lagged values of the unexpected return $\varepsilon_{t-1}$ to $\varepsilon_{t-\mathrm{q}}$ and the conditional variance $h_{t-1}$ to $h_{t-\mathrm{s}}$. The model can be written as:

$$
\begin{aligned}
& \Delta p_{t}=\alpha+\sum_{j=1}^{J} \sum_{k=0}^{K} \beta_{j k} Z_{j t-k}+\sum_{l=1}^{L} \lambda_{l} \Delta p_{t-l}+\varepsilon_{t} \\
& \varepsilon_{t}=v_{t} \sqrt{h_{t}} \quad \text { where } \quad v_{t} \sim N(0,1) \\
& h_{t}=\gamma_{0}+\sum_{q=1}^{Q} \gamma_{1 q} \varepsilon_{t-q}^{2}+\sum_{s=1}^{S} \gamma_{2 s} h_{t-s}
\end{aligned}
$$

There are many variations on the GARCH theme but some studies have indicated that a simple GARCH $(1,1)$ model — with one lag of the squared residual and one AR term — often outperforms other more complex specifications (Hansen and Lund (2005)) and we use this specification. However, our analysis of the volatility process for most commodities suggests that the conditional variance is sensitive to unexpected return shocks with lags of greater than one day (see Appendix Figure A2). Also, formal tests on the residuals of GARCH $(1,1)$ estimations still show the presence of heteroscedasticity for some commodities. To account for these features of the data, we present Bollerslev and Wooldridge (1992) standard errors, which are consistent in the presence of any remaining heteroscedasticity. We used likelihood ratio tests to identify the appropriate lag lengths and found that $K=2$ and $L=2$ in most cases. ${ }^{4}$

\section{Controlling for the U.S. dollar effect}

The model given by equation (3) may be missing one important aspect of commodity prices - a high sensitivity to other financial variables. For example, macroeconomic news may exert an indirect influence through a commodity's role as an effective hedge against lower interest rates or a depreciating U.S. dollar. In other words, might sensitivity to announcements merely reflect a relationship between the commodity and other financial assets, rather than the announcements themselves?

To address this, we also include the U.S. dollar exchange rate in our analysis, as there is strong evidence that commodity prices have been sensitive to the U.S. dollar over a long

\footnotetext{
${ }^{3}$ GARCH is an acronym for generalized autoregressive conditional heteroscedasticity.

${ }^{4}$ Details on the GARCH and likelihood ratio tests available from authors by request.
} 
period (Roache (2008)). We assume that all causality runs from the U.S. dollar-measured using the Federal Reserve's trade-weighted index against major trading partners - to the commodity price. ${ }^{5}$ This assumption is not uncontroversial, as commodity prices may influence exchange rates, at least for economies for which commodities account for a large share of exports or through the emerging soveriegn wealth fund (SWF) channel. However, recent evidence suggests that exchange rates play the dominant role as forcing variable-see Chen, Rogoff, and Rossi (2008) and Clements and Fry (2008).

We add the U.S. dollar index log change as an exogenous variable $(\Delta e)$, including $M$ lags, which would tend to introduce multicollinearity assuming the exchange rate is affected by economic announcements. The mean equation of the GARCH model (3) then becomes:

$$
\Delta p_{t}=\alpha+\sum_{j=1}^{J} \sum_{k=0}^{K} \beta_{j k} Z_{j t-k}+\sum_{l=1}^{L} \lambda_{l} \Delta p_{t-l}+\sum_{m=0}^{M} \theta_{m} \Delta e_{t-m}+\varepsilon_{t}
$$

\section{“Good news"_-bad news" and volatility effects}

Up to now, our analysis assumes that commodity price sensitivity to announcements is symmetrical and constant over time. However, the asymmetrical nature of commodity markets suggests that it is reasonable to question these assumptions. We explore two possible factors that might condition the response of commodity prices to announcements: first, do recent volatility patterns influence this sensitivity?; second, does it matter whether the news is "good" or "bad"?

By conditioning the price response, we lose observations and increase the number of coefficients to be estimated and with a sample size of a little over 10 years, this may leave insufficient information to capture these effects. Consequently, following earlier studies, we use a composite indicator for these conditioning models (see Galati and Ho (2003) and Erhmann and Fratscher (2005)). This composite aggregates the surprise element of the announcements into a single series, greatly simplifies the model, and increases the number of observations. The following analysis uses only U.S. announcements.

The composite is the sum of the standardized scores for each announcement, excluding monetary policy shocks, and we do not impose any sign changes on these scores. ${ }^{6} \mathrm{We}$

\footnotetext{
${ }^{5}$ Many commodity prices are correlated with other asset prices, but our focus is on the U.S. dollar due to the significantly inverse relationship between the two variables over a long period of time. Indeed, commodities are often viewed as a hedge against U.S. dollar depreciation versus other major currencies with large financial market-related turnover, such as the yen, the Euro and the pound sterling. Compared to the broader IMF nominal effective exchange rate index, the narrower coverage of the Federal Reserve's exchange rate index provides cleaner exposure to these currencies.

${ }^{6}$ In other words, the composite adds together the standardized surprises as calculated by equation (1) for each day. On a day with no announcement, the composite will have a value of zero (signifying no news). On a day
} 
compare our results against a base model that estimates the regression of the log change in the gold price $\Delta p$ on to a constant $\alpha$, the contemporaneous value and two lags of the composite indicator $Z$, and two autoregressive terms:

$$
\Delta p_{t}=\alpha+\sum_{k=0}^{2} \beta_{k} Z_{t-k}+\sum_{l=1}^{2} \lambda_{l} \Delta p_{t-l}+\varepsilon_{t}
$$

To assess whether volatility — often used as a measure of investor uncertainty-affects commodity price sensitivities, we condition our analysis on the level of gold price volatility over the preceding 30,60, and 90 days. We classify an announcement as arriving in a highvolatility period if the daily standard deviation of the commodity price for this period is above its sample average and vice versa for low volatility. The mean equation for the GARCH model then becomes:

$$
\Delta p_{t}=\alpha+\sum_{k=0}^{K} \beta_{k}^{\text {high }} Z_{t-k}^{\text {high }}+\sum_{k=0}^{K} \beta_{k}^{\text {low }} Z_{t-k}^{\text {low }}+\sum_{l=1}^{L} \lambda_{l} \Delta p_{t-l}+\varepsilon_{t}
$$

For the good news-bad news model, we define "good news" for the U.S. economy as an announcement surprise that should lead to an increase in the price of cyclically-sensitive assets; this would include higher-than-expected GDP growth, industrial production, non-farm payrolls, consumer confidence, or inflation. Of course, unexpectedly higher inflation is not necessarily "good" news for the U.S. economy, but we have classified this as good news, since it should, a priori, lead to an increase in commodity prices. The mean equation of the GARCH model we estimate can then be written as:

$$
\Delta p_{t}=\alpha+\sum_{k=0}^{K} \beta_{k}^{\text {good }} Z_{t-k}^{\text {good }}+\sum_{k=0}^{K} \beta_{k}^{\text {bad }} Z_{t-k}^{\text {bad }}+\sum_{l=1}^{L} \lambda_{l} \Delta p_{t-l}+\varepsilon_{t}
$$

\section{RESUlts}

\section{A. Scheduled Macroeconomic Announcements}

A number of macroeconomic announcements from the U.S. and the Euro area impact commodity prices (see Table 3 and Appendix Table A2 for more details). Some commodity

with just one announcement, the composite's value will be the standardized surprise of that announcement. On a day with more than one announcement, the surprise will be the summation of the individual standardized scores.

${ }^{7}$ The results are robust to the inclusion of monetary policy shocks. We excluded them to allow comparisons with previous literature. 
prices rise in response to announcements revealing a higher-than-expected level of economic activity. The results are not consistent across commodities, with energy products tending to exhibit little sensitivity, consistent with the findings of Kilian and Vega (2008). However, agricultural products and base metals show some evidence of pro-cyclical price sensitivity, which increases when we control for the typically inverse relationship of these commodities with the U.S. dollar (see Table 4 and Appendix Table A3 for more details). ${ }^{8}$ In contrast, gold prices tend to be counter-cyclical, with the price rising when activity indicators are surprisingly weak. U.S. retail sales, non-farm payrolls, housing starts, and the ISM survey tend to be the most influential indicators. The German IFO survey is also a strong influence, particularly for base metals, even when controlling for the effect of the U.S. dollar.

Table 3. Sensitivity to Macroeconomic Announcements January 1997-March 2009: Selected Results (Coefficients from estimated single equation GARCH regressions) 1/ 2/ 3/

\begin{tabular}{|c|c|c|c|c|c|c|c|}
\hline & & Crude & & & & & U.S. \\
\hline & Gold & Oil & Wheat & Corn & Copper & Aluminium & dollar \\
\hline Macroeconomic announcen & nents & & & & & & \\
\hline Advance retail sales & -0.03 & -0.42 & -0.02 & 0.06 & 0.07 & $0.15 * \star$ & 0.05 \\
\hline Change in non-farm payrolls & $-0.18 *$ & 0.12 & 0.23 * & $0.20 * *$ & 0.08 & 0.05 & $0.13 * * *$ \\
\hline Consumer confidence & $-0.15 * *$ & 0.18 & -0.13 & -0.09 & -0.03 & 0.02 & $0.08 * * *$ \\
\hline Consumer price index & 0.10 & 0.01 & 0.10 & 0.10 & $-0.30 * * *$ & $-0.26 * \star$ & -0.01 \\
\hline FOMC interest rate decision & -0.05 & -0.29 & $\ldots$ & $\ldots$ & 0.12 & 0.01 & 0.01 \\
\hline Advance GDP & -0.13 & -0.30 & -0.10 & -0.36 & 0.01 & 0.12 & $0.17 * \star$ \\
\hline Housing starts & -0.08 & 0.15 & -0.18 & -0.16 & 0.12 & $0.23 * \star$ & 0.00 \\
\hline Industrial production & -0.31 * & 0.27 & 0.02 & -0.04 & -0.10 & 0.27 & 0.08 * \\
\hline ISM manufacturing survey & -0.09 & -0.22 & 0.08 & -0.03 & 0.18 & 0.06 & $0.14^{* * *}$ \\
\hline ECB interest rate decision & $0.15 * *$ & -0.08 & 0.06 & $0.22 * *$ & 0.02 & 0.00 & -0.03 \\
\hline German IFO survey & 0.13 & 0.09 & 0.16 & 0.20 & $0.23 * *$ & 0.21 * & -0.11 \\
\hline Lagged by one day & & & & & & & \\
\hline Advance retail sales & -0.06 & -0.47 & -0.13 & 0.05 & -0.11 & -0.06 & $0.05 * *$ \\
\hline Change in non-farm payrolls & 0.00 & 0.15 & 0.08 & 0.15 & -0.03 & $0.23 * \star \star$ & 0.00 \\
\hline Existing home sales & 0.06 & 0.34 * & 0.08 & 0.17 & -0.15 & -0.10 & 0.02 \\
\hline FOMC interest rate decision & $-0.26 * \star \star$ & 0.16 & -0.11 & -0.18 & -0.09 & -0.14 & $0.18 * * *$ \\
\hline ISM manufacturing survey & 0.01 & 0.06 & -0.04 & -0.06 & $0.25 * *$ & 0.13 & -0.03 \\
\hline PPI ex-food and energy & $-0.19 * \star$ & -0.15 & -0.06 & -0.10 & -0.05 & -0.08 & 0.02 \\
\hline German IFO survey & $0.22 * * *$ & -0.13 & 0.11 & 0.14 & 0.18 * & 0.12 & -0.04 \\
\hline
\end{tabular}

Source: Authors' estimates.

$1 /$ Coefficients shown are those that were statistically significant at the 10 percent level or more.

2/ The coefficient on each announcement is multiplied by 100 and represents the percent change in the price of the nearest gold futures contract and U.S. dollar index for a 1-standard deviation surprise. $3 /$ Bollerslev-Woolridge standard errors, which are robust to remaining heteroscedasticity. Significance at the 99 percent, 95 percent, and 90 percent levels are denoted by ***, ${ }^{\star \star}$, and * respectively.

\footnotetext{
${ }^{8}$ The inverse relationship of some commodity prices with the U.S. dollar will tend to dampen their measured pro-cyclical sensitivity in the absence of a U.S. dollar control variable.
} 
For gold, this apparent counter-cyclicality in the very short-term contradicts the results from earlier research using sample periods that stretch between 1970 and the early 1990s. Previous work had tended to find that the gold price was pro-cyclical; i.e. it rose when U.S. inflation increased or activity indicators strengthened by more than the consensus had anticipated. Our results do not imply that the inflation-hedging properties of gold have diminished, but instead suggests two features of gold: first, in the short-term sensitivity is higher to market expectations for real interest rates; second, gold is seen as a safe-haven during "bad times".

The shift to a more pro-active U.S. monetary policy stance in the 1980 s effectively substituted real interest volatility for inflation volatility. This implies that positive inflation surprises increase the probability of counter-cyclical monetary tightening and higher real interest rates, which tend to appreciate the U.S. dollar and depress gold prices - see Kaul (1987) for a similar argument for equity markets. Over longer time horizons than 1-2 days, the evidence suggests that real interest rates may be less responsive to inflation surprises than the market had feared, which can ultimately lead to positive effects on the gold price from inflation shocks, as noted by Attié and Roache (2009).

We also find that Euro area indicators that point to stronger activity or higher interest rates tend to increase the gold price and depreciate the U.S. dollar, providing further evidence of gold's dollar-hedging characteristics. Indeed, the U.S. dollar's influence is unsurprisingly strong for gold, with the effect of some individual announcements losing significance when a control for this relationship is included in the model. In contrast, the pro-cyclical sensitivities are heightened for other commodities once we add the U.S. dollar as a regressor (Appendix Table 3).

Where it is significant, commodity prices tend to be inversely related to Federal Reserve interest rate surprises, confirming the results of previous research. Even crude oil, which is quite insensitive to most news events, has exhibited this relationship since 2001. However, we found very few occasions for which the market has been surprised by the interest rate announcements following regularly scheduled FOMC meetings and these results are influenced by a small number of datapoints. There are more datapoints for ECB interest rate surprises and, when controlling for the U.S. dollar, there is evidence that precious and base metals prices are inversely related to interest rate shocks. ${ }^{9}$ We also included U.K. interest rate decisions, but the results were strongly influenced by the very large surprise rate cut in November 2008. Excluding this outlier, U.K. interest rate decisions were not significant.

The conclusions are qualitatively similar when we break the sample into two sub-periods based on the trend of the broad CRB commodity price index. During the first subperiod from 1997 to November 2001, this index was either trending lower or trading within a range, while

\footnotetext{
${ }^{9}$ It is important to control for the U.S. dollar in this case as the U.S. dollar will tend to appreciate (depreciate) when the ECB unexpectedly cuts (hikes) its benchmark policy interest rate.
} 
the second period, from December 2001 to March 2009, is characterized by a sharp rise and subsequent decline. ${ }^{10}$ Our aim in this analysis is to assess whether short-term price dynamics have changed due to the increasing commodity market participation by financial investors. The number of indicators affecting prices and the degrees of pro-cyclical sensitivity among non-gold commodities have tended to rise since 2001, but the overall results outlined above remain intact (see Appendix Tables A3 and A4).

Table 4. Sensitivity to Macroeconomic Announcements January 1997-May 2009: Selected Results (Including U.S. dollar control variables) 1/ 2/ 3/

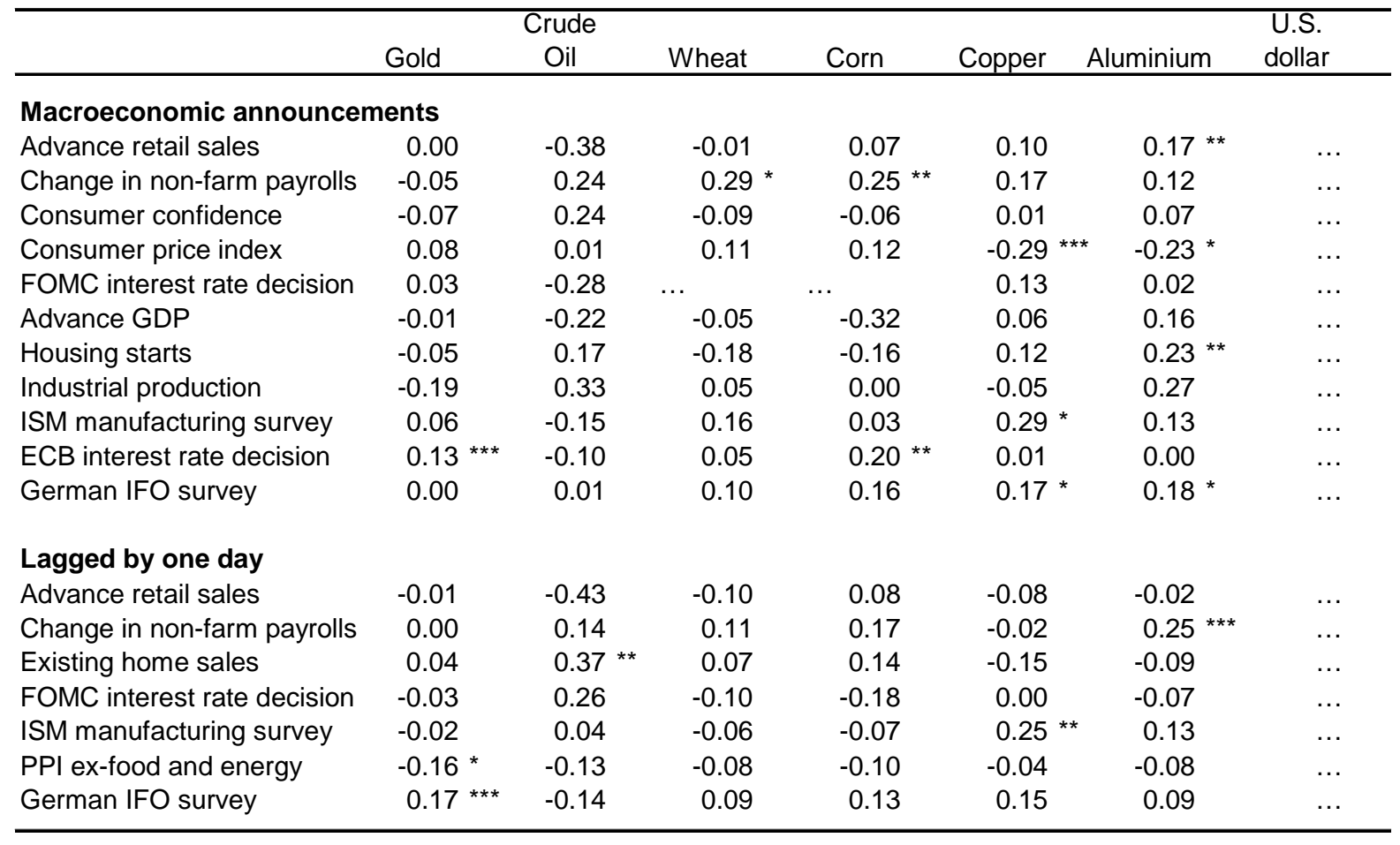

Source: Authors' estimates.

$1 /$ Coefficients shown are those that were statistically significant at the 10 percent level or more in the benchmark model shown in Table 3.

2/ The coefficient on each announcement is multiplied by 100 and represents the percent change in the price of the nearest gold futures contract and U.S. dollar index for a 1-standard deviation surprise. $3 /$ Bollerslev-Woolridge standard errors, which are robust to remaining heteroscedasticity. Significance at the 99 percent, 95 percent, and 90 percent levels are denoted by ${ }^{\star \star \star}$, ${ }^{\star *}$, and * respectively.

\footnotetext{
${ }^{10}$ Chow tests based on breakpoints around November 2001 indicate that it was not possible to reject the null hypothesis of model stability over the entire 1997-2009 sample at the 5 percent level for almost all commodities.
} 
Table 5. Sensitivity to Macroeconomic Announcements December 2001-May 2009: Selected Results (Including U.S. dollar control variables) 1/ 2/ 3/

\begin{tabular}{|c|c|c|c|c|c|c|c|}
\hline & \multicolumn{3}{|c|}{ Crude } & \multirow[b]{2}{*}{ Corn } & \multirow[b]{2}{*}{ Copper } & \multirow[b]{2}{*}{ Aluminium } & \multirow{2}{*}{$\begin{array}{l}\text { U.S. } \\
\text { dollar }\end{array}$} \\
\hline & Gold & Oil & Wheat & & & & \\
\hline \multicolumn{8}{|c|}{ Macroeconomic announcements } \\
\hline Advance retail sales & 0.00 & -0.38 & -0.01 & 0.07 & 0.10 & $0.17 * \star$ & $\ldots$ \\
\hline Change in non-farm payrolls & -0.05 & 0.24 & 0.29 * & $0.25 * *$ & 0.17 & 0.12 & $\ldots$ \\
\hline Consumer confidence & -0.07 & 0.24 & -0.09 & -0.06 & 0.01 & 0.07 & $\ldots$ \\
\hline Consumer price index & 0.08 & 0.01 & 0.11 & 0.12 & $-0.29 * * *$ & $-0.23 *$ & $\ldots$ \\
\hline FOMC interest rate decision & 0.03 & -0.28 & $\ldots$ & $\ldots$ & 0.13 & 0.02 & $\ldots$ \\
\hline Advance GDP & -0.01 & -0.22 & -0.05 & -0.32 & 0.06 & 0.16 & $\ldots$ \\
\hline Housing starts & -0.05 & 0.17 & -0.18 & -0.16 & 0.12 & $0.23 * *$ & $\ldots$ \\
\hline Industrial production & -0.19 & 0.33 & 0.05 & 0.00 & -0.05 & 0.27 & $\ldots$ \\
\hline ISM manufacturing survey & 0.06 & -0.15 & 0.16 & 0.03 & $0.29 *$ & 0.13 & $\ldots$ \\
\hline ECB interest rate decision & $0.13 * \star \star$ & -0.10 & 0.05 & $0.20 * \star$ & 0.01 & 0.00 & $\ldots$ \\
\hline German IFO survey & 0.00 & 0.01 & 0.10 & 0.16 & 0.17 * & 0.18 * & $\ldots$ \\
\hline \multicolumn{8}{|l|}{ Lagged by one day } \\
\hline Advance retail sales & -0.01 & -0.43 & -0.10 & 0.08 & -0.08 & -0.02 & $\ldots$ \\
\hline Change in non-farm payrolls & 0.00 & 0.14 & 0.11 & 0.17 & -0.02 & $0.25 * \star \star$ & $\ldots$ \\
\hline Existing home sales & 0.04 & $0.37 * \star$ & 0.07 & 0.14 & -0.15 & -0.09 & $\ldots$ \\
\hline FOMC interest rate decision & -0.03 & 0.26 & -0.10 & -0.18 & 0.00 & -0.07 & $\ldots$ \\
\hline ISM manufacturing survey & -0.02 & 0.04 & -0.06 & -0.07 & $0.25 \star *$ & 0.13 & $\ldots$ \\
\hline PPI ex-food and energy & $-0.16 *$ & -0.13 & -0.08 & -0.10 & -0.04 & -0.08 & $\ldots$ \\
\hline German IFO survey & $0.17 \star \star \star$ & -0.14 & 0.09 & 0.13 & 0.15 & 0.09 & $\ldots$ \\
\hline
\end{tabular}

Source: Authors' estimates.

$1 /$ Coefficients shown are those that were statistically significant at the 10 percent level or more in the benchmark model shown in Table 3.

2/ The coefficient on each announcement is multiplied by 100 and represents the percent change in the price of the nearest gold futures contract and U.S. dollar index for a 1-standard deviation surprise. 3/ Bollerslev-Woolridge standard errors, which are robust to remaining heteroscedasticity. Significance at the 99 percent, 95 percent, and 90 percent levels are denoted by ${ }^{* \star *},{ }^{* *}$, and * respectively.

\section{B. “Good News”, “Bad News”, and Volatility}

\section{Gold price more sensitive to "bad news"}

Results indicate that there are few commodities for which the good-bad news distinction makes any difference, with one exception being gold — bad news affects the gold price much more than good news (Table 6). The coefficient on the bad news aggregate is statistically significant and much higher than that on good news, a result that is maintained even when we control for the U.S. dollar (Table A7). We also show the effect on the U.S. dollar which is, perhaps unsurprisingly, symmetric for both types of news. This is consistent with the view that gold is a safe haven and financial assets - in this case gold futures-experience greater volatility during periods in which economic or financial conditions deteriorate. There is also the potential for significant non-linearities in gold price sensitivities, although we do not address that possibility in this paper. 


\section{Gold price more sensitive when uncertainty is high}

For the U.S. dollar we confirm the standard result that sensitivity is higher following a period of elevated volatility. For almost all commodities, except gold, however, the type of news does not have a significant impact. The impact of news on gold is stronger following periods of volatility, but only when we control for the U.S. dollar (Table A7).

Table 6. Sensitivity to Macroeconomic Announcements Conditioned on High/Low Volatility and Good/Bad News January 1997-March 2009: Selected Results 1/ 2/

\begin{tabular}{|c|c|c|c|c|c|c|c|c|}
\hline & Gold & $\begin{array}{c}\text { Crude } \\
\text { oil }\end{array}$ & Wheat & Corn & Soybeans & Copper & Aluminium & $\begin{array}{l}\text { US } \\
\text { dollar }\end{array}$ \\
\hline Aggregate news t & $-0.08 * \star \star$ & 0.01 & 0.01 & -0.02 & 0.00 & 0.02 & 0.05 & $0.05^{* \star \star}$ \\
\hline Aggregate news $\mathrm{t}-1$ & -0.03 & -0.04 & -0.02 & 0.00 & -0.01 & -0.03 & 0.00 & 0.01 \\
\hline Aggregate news $t-2$ & 0.02 & -0.05 & 0.06 & -0.02 & -0.01 & 0.07 * & 0.05 & 0.01 \\
\hline \multicolumn{9}{|c|}{$\begin{array}{l}\text { Good/ bad news with no US\$ control } \\
\text { Aggregate news regressor }\end{array}$} \\
\hline Good news t & -0.02 & -0.05 & 0.09 & $0.10 *$ & 0.10 * & 0.09 & $0.12 \star \star \star *$ & $0.05^{* \star \star}$ \\
\hline Good news t-1 & -0.03 & -0.09 & -0.04 & -0.08 * & 0.02 & 0.01 & -0.07 & 0.01 \\
\hline Bad news t & $-0.17 * * \star$ & 0.08 & -0.08 & $-0.20 * * *$ & $-0.13 * *$ & -0.05 & -0.04 & $0.05^{* * \star}$ \\
\hline Bad news t-1 & -0.03 & 0.01 & 0.02 & 0.11 & -0.03 & -0.06 & 0.08 & 0.01 \\
\hline \multicolumn{9}{|c|}{$\begin{array}{l}\text { High/ low volatility with no US } \$ \text { control } \\
\text { Regressors }\end{array}$} \\
\hline $\mathrm{Hi}$ vol - news t & -0.07 & -0.01 & -0.16 & -0.19 & -0.16 & -0.04 & 0.04 & $0.12^{\star \star \star}$ \\
\hline Hi vol - news t-1 & -0.07 & -0.20 & -0.07 & -0.16 & -0.07 & 0.01 & -0.06 & -0.03 \\
\hline Lo vol - news t & $-0.09 * \star \star$ & 0.02 & 0.06 & 0.01 & 0.02 & 0.03 & 0.05 & $0.03^{* \star \star}$ \\
\hline Lo vol - news t-1 & -0.02 & 0.00 & 0.00 & 0.04 & 0.01 & -0.03 & 0.01 & 0.01 \\
\hline
\end{tabular}

Source: Authors' estimates.

$1 /$ The coefficient on each announcement is multiplied by 100 and represents the percent change in the price of the nearest gold futures contract and U.S. dollar index for a 1-standard deviation surprise. 2/ Bollerslev-Woolridge standard errors, which are robust to remaining heteroscedasticity.

Significance at the 99 percent, 95 percent, and 90 percent levels are denoted by ${ }^{\star \star \star}$, ${ }^{\star \star}$, and * respectively.

\section{Conclusion}

Our results suggest that commodities are not just financial assets and gold is not just another commodity. Some commodity prices are influenced by the surprise element in macroeconomic news, with evidence of a pro-cyclical bias, particularly when we control for the effect of the U.S. dollar. Commodities tend to be less sensitive than financial assets-for example, crude oil, the most actively traded commodity futures contract, shows no significant responsiveness to almost all announcements. However, as commodity markets have become financialized in recent years, so their sensitivity appears to have risen somewhat to both macroeconomic news and surprise interest rate changes. 
The gold price is sensitive to a number of scheduled U.S. and Euro area macroeconomic announcements_-including retail sales, non-farm payrolls, and inflation. Gold's high sensitivity to real interest rates and its unique role as a safe-haven and store of value typically leads to a counter-cyclical reaction to surprise news, in contrast to their commodities. It also shows a particularly high sensitivity to negative surprises that might lead financial investors to become more risk averse.

These results have a number of implications. To reduce the uncertainty of the return on gold transactions, traders may wish to time their orders flow so as to avoid the release of information that has been shown to affect prices. For longer-term market participants, these results provide confirmation of the pro-cyclical bias of many commodities and gold's role as a safe-haven during periods of economic uncertainty. Looking forward, one key issue will be the extent to which increasing financialization heightens the sensitivity of commodities to macroeconomic developments. 


\section{REFERENCES}

Andersen, Torben G., Tim Bollerslev, Francis X. Diebold, and Clara Vega, 2003, "Micro Effects of Macro Announcements: Real-Time Price Discovery in Foreign Exchange,” American Economic Review, Vol. 93, pp. 38-62.

Antoniou, Antonios, and Andrew J. Foster, 1992, “The Effects of Futures Trading on Spot Price Volatility: Evidence for Brent Crude Oil Using GARCH,” Journal of Business Finance \& Accounting, Vol. 19 No. 4, pp. 473-484.

Attié, Alexander P., and Shaun K. Roache, 2009, “Inflation Hedging for Long-Term Investors,” IMF Working Paper, No. 09/90.

Balduzzi, Pierluigi, Edwin J. Elton, and T. Clifton Green, 2001, “Economic News and Bond Prices: Evidence from the U.S. Treasury Market,” The Journal of Financial and Quantitative Analysis, Vol. 36, No. 4, pp. 523-543.

Barnhart, Scott W., 1989, “The Effects of Macroeconomic Announcements on Commodity Prices,” American Journal of Agricultural Economics, Vol. 71, No. 2, pp. 389-403.

Bollerslev, Tim and Jeffrey M. Wooldridge, 1992, “Quasi-Maximum Likelihood Estimation and Inference in Dynamic Models with Time Varying Covariances,” Econometric Reviews, 11, pp. 143-172.

Cai, Jun, Yan-Leung Cheung, Michael C. S. Wong, 2001, "What moves the gold market?” Journal of Futures Markets, Volume 21 Issue 3, pp. 257-278.

Chen, Yu-Chin, Kenneth Rogoff, and Barbara Rossi, 2008, “Can Exchange Rates Forecast Commodity Prices?,” Economic Research Initiatives at Duke (ERID) Working Paper, No. 1.

Christie-David, Rohan, Mukesh Chaudhry, and Timothy W. Koch, 2000, “Do Macroeconomics News Releases Affect Gold and Silver Prices?,” Journal of Economics and Business, 52, pp. 405-421.

Clements, Kenneth W., and Renee Fry, 2008, “Commodity Currencies and Currency Commodities,” Resources Policy, Volume 33, Issue 2, pp. 55-73.

Cornell, Bradford, and Kenneth R. French, 1986, “Commodity Own Rates, Real Interest Rates, and Money Supply Announcements,” Journal of Monetary Economics, 18, pp. 3-20.

Ehrmann, M., and M. Fratzscher, 2005, "Exchange Rates and Fundamentals: New Evidence from Real-Time Data,” Journal of International Money and Finance, 24, pp. 317-341.

Engle, Robert F. and Kenneth F. Kroner, 1995, “Multivariate Simultaneous Generalized ARCH,” Econometric Theory, Vol. 11, No.1, pp. 122-150. 
Fleming, M. J., and E. M. Remelona, 1999, "Price Formation and Liquidity in the U.S. Treasury Market: The Response to Public Information,” Journal of Finance, 54, pp. 19011915.

Frankel, Jeffrey A., 2008, “The Effect of Monetary Policy on Real Commodity Prices,” in Asset Prices and Monetary Policy, John Campbell, ed., U. of Chicago Press, pp. 291-327.

Frankel, Jeffrey A., and Gikas A. Hardouvelis, 1985, “Commodity Prices, Money Surprises and Fed Credibility,” Journal of Money, Credit and Banking, Vol. 17, No. 4, Part 1, pp. 425438.

Galati, Gabriele, and Corrine Ho, 2003, "Macroeconomic News and the Euro/Dollar Exchange Rate” Economic Notes, vol. 32, no. 3, pp. 371-398.

Ghura, Dhaneshwar, 1990, "How Commodity Prices Respond to Macroeconomic News," World Bank PRE Working Paper, No. 354.

Hansen, Peter, and Asger Lund, 2005, “A Forecast Comparison of Volatility Models: Does Anything Beat a GARCH (1,1)?,” Journal of Applied Econometrics, 20, pp. 873-889.

Hess, Dieter, He Huang, and Alexandra Niessen, 2008, “How Do Commodity Futures Respond to Macroeconomic News?,” Journal of Financial Markets and Portfolio Management, Volume 22, Number 2.

Kaul, Gautam, 1987, “Stock Returns and Inflation-The Role of the Monetary Sector," Journal of Financial Economics, Vol. 18, No. 2, pp. 253-276.

Kilian, Lutz, and Clara Vega, 2008, "Do Energy Prices Respond to U.S. Macroeconomic News? A Test of the Hypothesis od Predetermined Energy Prices,” Federal Reserve International Discussion Paper, No. 957.

Payne, R., 2003, “Informed trade in Spot Foreign Exchange Markets: An Empirical Investigation,” Journal of International Economics, 61, pp. 307-328.

Roache, Shaun, 2008, “Commodities and the Market Price of Risk,” IMF Working Paper, No. 08/221.

Rossi, Marco, 1998, “Economic Announcements and the Timing of Public Debt Auctions,” IMF Working Paper, No. 98/44.

Yang, Jian, R. Brian Balyeat, and David J. Leatham, 2005, "Futures Trading Activity and Commodity Cash Price Volatility,” Journal of Business Finance \& Accounting, 32(1), pp. 297-323. 


\section{APPENDIX}

Table A1. Commodity Futures Contracts Specification

\begin{tabular}{llll}
\hline Contract & Exchange 1/ & Specification summary 2/ & Closing price time \\
\hline Gold & COMEX & 100 troy ounces & $17: 15$ EST \\
Silver & COMEX & 5,000 troy ounces & $17: 15$ EST \\
Platinum & NYMEX & 50 troy ounces & $17: 15$ EST \\
Palladium & NYMEX & 100 troy ounces & $17: 15$ EST \\
Oil & NYMEX & Light, sweet crude, 1,000 barrels & $17: 15$ EST \\
Heating oil & NYMEX & 42,000 barrels & $17: 15$ EST \\
Natural gas & NYMEX & 10,000 million British thermal units & $17: 15$ EST \\
Wheat & CBOT & 5,000 bushels & $13: 15$ CST \\
Corn & CBOT & 5,000 bushels & $13: 15$ CST \\
Soybeans & CBOT & 5,000 bushels & $13: 15$ CST \\
Copper & COMEX & High grade, 25,000 pounds & $17: 15$ EST \\
Aluminium & COMEX & 44,000 pounds & $17: 15$ EST \\
\hline
\end{tabular}

Source: COMEX division of NYMEX, NYMEX, and CBOT.

$1 /$ COMEX is a division of NYMEX, the New York Mercantile Exchange. CBOT is an abbreviation of the Chicago Board of Trade.

2/ Refer to individual exchanges for full specifications. 
Table A2. U.S. and Euro area Macroeconomic Announcements: Summary Statistics, January 1997-April 20091/

(Monthly percent change, unless otherwise specified)

\begin{tabular}{|c|c|c|c|}
\hline Macroeconomic announcement & $\begin{array}{c}\text { Average } \\
\text { actual }\end{array}$ & $\begin{array}{l}\text { Average } \\
\text { surprise }\end{array}$ & $\begin{array}{c}\text { Standard } \\
\text { deviation } \\
\text { surprise } \\
\end{array}$ \\
\hline Advance retail sales & 0.2 & 0.0 & 0.6 \\
\hline Change in non-farm payrolls (thousands) & 43.6 & -24.0 & 77.5 \\
\hline Consumer confidence (index) & 89.8 & -0.3 & 5.0 \\
\hline Consumer price index & 0.2 & 0.0 & 0.2 \\
\hline Employment cost index (quarterly percent change) & 0.7 & 0.0 & 0.2 \\
\hline Existing home sales & -1.1 & 0.1 & 3.3 \\
\hline FOMC interest rate decision (absolute basis point change) & 18 & -1 & 6 \\
\hline Advance GDP (annualized quarterly percent change) & 2.5 & 0.0 & 0.0 \\
\hline Housing starts (thousands) & 1,648 & 9.4 & 101 \\
\hline Industrial production & 0.1 & 0.0 & 0.0 \\
\hline ISM manufacturing survey & 52.9 & 0.1 & 2.1 \\
\hline PPI ex-food and energy (MoM) & 0.2 & 0.0 & 0.5 \\
\hline ECB interest rate decision (absolute basis point change) & 30 & 3 & 8 \\
\hline German IFO survey & 96.7 & 0.1 & 1.2 \\
\hline U.K. interest rate decision (absolute basis point change) & 10 & 4 & 9 \\
\hline
\end{tabular}

Source: Bloomberg; Authors' estimates

$1 /$ Actuals denote the data as of the release date and do not reflect subsequent revisions. 
Table A3. Commodity Price Sensitivity to Economic Announcements, January 1997-May 2009 1/

\begin{tabular}{|c|c|c|c|c|c|c|c|c|c|c|c|c|}
\hline & Gold & Silver & Platinum & Palladium & $\begin{array}{c}\text { Crude } \\
\text { Oil } \\
\end{array}$ & $\begin{array}{l}\text { Heating } \\
\text { Oil }\end{array}$ & $\begin{array}{c}\text { Natural } \\
\text { Gas }\end{array}$ & Wheat & Corn & Soybeans & Copper A & Aluminium \\
\hline \multicolumn{13}{|c|}{ Macroeconomic announcements } \\
\hline Advance retail sales & -0.03 & 0.04 & 0.01 & 0.02 & -0.42 & -0.43 & -0.20 & -0.02 & 0.06 & -0.04 & 0.07 & $0.15 * \star$ \\
\hline Change in non-farm payrolls & -0.18 * & -0.06 & 0.08 & -0.03 & 0.12 & 0.17 & 0.06 & 0.23 * & $0.20 * *$ & 0.06 & 0.08 & 0.05 \\
\hline Consumer confidence & $-0.15 * \star$ & 0.01 & -0.17 & $-0.40 * \star$ & 0.18 & 0.19 & $0.80 * \star *$ & -0.13 & -0.09 & 0.00 & -0.03 & 0.02 \\
\hline Consumer price index & 0.10 & 0.03 & 0.11 & 0.19 & 0.01 & -0.07 & -0.17 & 0.10 & 0.10 & 0.15 & $-0.30 * * *$ & ** -0.26 ** \\
\hline Employment cost index & 0.05 & 0.16 & 0.28 & 0.48 & 0.20 & 0.14 & 0.19 & -0.06 & 0.18 & 0.46 ** & -0.24 & -0.11 \\
\hline Existing home sales & -0.05 & -0.08 & -0.11 & 0.01 & -0.12 & $-0.29 *$ & $-0.45 *$ & 0.08 & -0.17 & 0.02 & 0.15 & -0.05 \\
\hline FOMC interest rate decision & -0.05 & -0.07 & $-0.41 * *$ & -0.06 & -0.29 & -0.21 & -0.40 & $\ldots$ & $\ldots$ & $\ldots$ & 0.12 & 0.01 \\
\hline Advance GDP & -0.13 & -0.04 & 0.06 & 0.35 & -0.30 & -0.16 & 0.04 & -0.10 & -0.36 & $-0.36 * *$ & 0.01 & 0.12 \\
\hline Housing starts & -0.08 & -0.03 & 0.06 & 0.11 & 0.15 & 0.11 & $-0.41 * *$ & -0.18 & -0.16 & -0.20 & 0.12 & 0.23 ** \\
\hline Industrial production & -0.31 * & -0.26 & -0.12 & 0.34 & 0.27 & 0.22 & -0.06 & 0.02 & -0.04 & -0.03 & -0.10 & 0.27 \\
\hline ISM manufacturing survey & -0.09 & -0.09 & -0.11 & 0.06 & -0.22 & -0.19 & -0.32 & 0.08 & -0.03 & -0.05 & 0.18 & 0.06 \\
\hline PPI ex-food and energy & -0.02 & 0.12 & -0.03 & 0.00 & 0.07 & -0.05 & -0.52 * & -0.04 & -0.10 & -0.06 & -0.04 & 0.08 \\
\hline ECB interest rate decision & $0.15 * \star$ & 0.06 & -0.49 & 0.27 & -0.08 & -0.33 & -0.30 & 0.06 & $0.22 * *$ & $-0.08 * * \star$ & 0.02 & 0.00 \\
\hline German IFO survey & 0.13 & 0.11 & $0.34 * * *$ & * 0.06 & 0.09 & 0.10 & $0.97 * \star \star$ & 0.16 & 0.20 & 0.24 & 0.23 ** & 0.21 * \\
\hline UK interest rate decision & -0.06 & -0.17 & -0.08 & -0.01 & 0.04 & 0.14 & 0.20 & -0.13 & 0.05 & $0.05 *$ & 0.00 & 0.08 \\
\hline \multicolumn{13}{|l|}{ Lagged by one day } \\
\hline Change in non-farm payrolls & 0.00 & -0.08 & -0.14 & -0.21 & 0.15 & 0.25 & -0.01 & 0.08 & 0.15 & 0.21 * & -0.03 & $0.23 * \star *$ \\
\hline Consumer confidence & 0.01 & 0.01 & 1.17 & 0.32 & -0.30 & -0.24 & 0.25 & -0.05 & -0.02 & -0.09 & -0.07 & -0.06 \\
\hline Consumer price index & -0.13 & -0.14 & 0.06 & 0.02 & -0.05 & 0.17 & 0.03 & -0.18 & -0.12 & -0.18 * & -0.13 & -0.06 \\
\hline Employment cost index & 0.03 & -0.15 & -0.16 & 0.64 * & 0.04 & -0.16 & 0.66 & -0.15 & -0.05 & $-0.20 *$ & 0.20 & -0.07 \\
\hline Existing home sales & 0.06 & 0.11 & $-0.58 * * *$ & $-0.29 *$ & 0.34 * & $0.41 * \star$ & -0.26 & 0.08 & 0.17 & 0.35 & -0.15 & -0.10 \\
\hline FOMC interest rate decision & $-0.26 * \star \star$ & 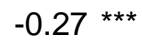 & $-0.67 * \star$ & -0.18 & 0.16 & 0.09 & $0.72 * \star \star$ & -0.11 & -0.18 & -0.15 & -0.09 & -0.14 \\
\hline Advance GDP & 0.01 & 0.02 & -0.14 & 0.32 & 0.16 & 0.23 & 0.84 & -0.01 & 0.15 * & $0.18 * \star *$ & 0.06 & 0.11 \\
\hline ISM manufacturing survey & 0.01 & 0.18 & -0.01 & 0.15 & 0.06 & 0.22 & $0.66 * * *$ & -0.04 & -0.06 & -0.07 & $0.25 * *$ & 0.13 \\
\hline PPI ex-food and energy & $-0.19 * \star$ & -0.05 & -0.18 * & $-0.28 *$ & -0.15 & 0.01 & -0.68 & -0.06 & -0.10 & -0.13 & -0.05 & -0.08 \\
\hline ECB interest rate decision & -0.08 & -0.02 & 0.02 & 0.11 & 0.09 & 0.20 & 0.20 & 0.23 * & 0.02 & 0.22 ** & -0.01 & -0.02 \\
\hline German IFO survey & $0.22 \star * \star$ & $0.23 * * *$ & $0.39 * * \star$ & $0.29 * *$ & -0.13 & -0.25 & 0.14 & 0.11 & 0.14 & 0.09 & 0.18 * & 0.12 \\
\hline UK interest rate decision & 0.07 & $0.36 * * *$ & $0.19 * *$ & $0.42 * * *$ & -0.07 & 0.01 & $0.70 * \star \star$ & $0.36 * * *$ & 0.21 * & 0.19 * & -0.10 & -0.13 \\
\hline Lagged price t-1 & 0.00 & -0.02 & 0.02 & $0.11 * \star \star$ & -0.01 & -0.02 & $-0.03 *$ & 0.01 & 0.04 ** & -0.02 & $-0.07 * * *$ & ** $-0.08 * * *$ \\
\hline Lagged price t-2 & -0.02 & 0.03 & $-0.06 * * *$ & * $\quad-0.04$ ** & $-0.05 * * *$ & -0.03 & 0.00 & -0.02 & 0.00 & 0.03 * & -0.01 & -0.02 \\
\hline
\end{tabular}

Source: Authors' estimates.

1/ The coefficient on each announcement is multiplied by 100 and represents the percent change in the price of the nearest gold futures contract and U.S. dollar index for a 1-standard deviation surprise. Bollerslev-Woolridge standard errors, which are robust to remaining heteroscedasticity. Significance at the 99 percent, 95 percent, and 90 percent levels are denoted by ***, ${ }^{\star \star}$, and * respectively. Only statistically significant coefficients are shown at lag 1. 
Table A4. Commodity Price Sensitivity to Economic Announcements (with U.S. dollar control) January 1997-May 2001

\begin{tabular}{|c|c|c|c|c|c|c|c|c|c|c|c|c|}
\hline & Gold & Silver & Platinum & Palladium & $\begin{array}{c}\text { Crude } \\
\text { Oil }\end{array}$ & $\begin{array}{c}\text { Heating } \\
\text { Oil }\end{array}$ & $\begin{array}{c}\text { Natural } \\
\text { Gas }\end{array}$ & Wheat & Corn & Soybeans & Copper & Aluminium \\
\hline \multicolumn{13}{|c|}{ Macroeconomic announcements } \\
\hline Advance retail sales & 0.00 & 0.06 & 0.06 & 0.15 & -0.38 & -0.36 & -0.12 & -0.01 & 0.07 & -0.01 & 0.10 & $0.17 * *$ \\
\hline Change in non-farm payrolls & -0.05 & 0.07 & -0.01 & 0.13 & 0.24 & 0.28 & 0.16 & 0.29 * & 0.25 ** & 0.10 & 0.17 & 0.12 \\
\hline Consumer confidence & -0.07 & 0.12 & 0.17 & -0.33 * & 0.24 & 0.26 & $0.84 * \star *$ & -0.09 & -0.06 & 0.02 & 0.01 & 0.07 \\
\hline Consumer price index & 0.08 & 0.05 & 0.09 & 0.15 & 0.01 & -0.07 & -0.18 & 0.11 & 0.12 & 0.19 & $-0.29 * * *$ & $*-0.23$ * \\
\hline Employment cost index & 0.00 & 0.14 & 0.16 & 0.43 & 0.15 & 0.06 & 0.19 & -0.06 & 0.14 & 0.44 ** & -0.26 & -0.17 \\
\hline Existing home sales & -0.04 & -0.05 & -0.15 & 0.03 & -0.11 & -0.31 * & $-0.47 *$ & 0.07 & -0.17 & 0.01 & 0.15 & -0.06 \\
\hline FOMC interest rate decision & 0.03 & -0.06 & $-0.43 * \star$ & -0.02 & -0.28 & -0.20 & -0.39 & & & & 0.13 & 0.02 \\
\hline Advance GDP & -0.01 & 0.18 & 0.09 & 0.55 * & -0.22 & -0.07 & 0.14 & -0.05 & -0.32 & 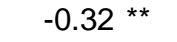 & 0.06 & 0.16 \\
\hline Housing starts & -0.05 & -0.07 & 0.05 & 0.10 & 0.17 & 0.13 & $-0.42 \star \star$ & -0.18 & -0.16 & -0.19 & 0.12 & $0.23 * \star$ \\
\hline Industrial production & -0.19 & -0.18 & -0.19 & 0.40 * & 0.33 & 0.28 & -0.02 & 0.05 & 0.00 & 0.00 & -0.05 & 0.27 \\
\hline ISM manufacturing survey & 0.06 & 0.10 & 0.03 & 0.22 & -0.15 & -0.11 & -0.26 & 0.16 & 0.03 & 0.02 & 0.29 * & 0.13 \\
\hline PPI ex-food and energy & -0.03 & 0.08 & -0.11 & -0.05 & 0.06 & -0.05 & $-0.50 *$ & -0.06 & -0.13 & -0.08 & -0.07 & 0.04 \\
\hline ECB interest rate decision & $0.13 * \star \star$ & 0.02 & -0.41 & 0.20 & -0.10 & -0.34 & -0.30 & 0.05 & 0.20 ** & $-0.09 * * *$ & 0.01 & 0.00 \\
\hline German IFO survey & 0.00 & 0.00 & 0.16 & -0.02 & 0.01 & 0.01 & $0.88^{* * *}$ & 0.10 & 0.16 & 0.21 & 0.17 * & 0.18 * \\
\hline UK interest rate decision & 0.06 & -0.09 & -0.04 & 0.03 & 0.06 & 0.16 & 0.21 & -0.10 & 0.08 & 0.08 * & 0.04 & 0.07 \\
\hline \multicolumn{13}{|l|}{ Lagged by one day } \\
\hline Change in non-farm payrolls & 0.00 & -0.04 & -0.14 & -0.19 & 0.14 & 0.25 & -0.01 & 0.11 & 0.17 & 0.23 * & -0.02 & $0.25 * \star \star$ \\
\hline Employment cost index & 0.10 & -0.11 & -0.19 & 0.66 * & 0.06 & -0.15 & 0.67 & -0.13 & -0.03 & $-0.15 *$ & 0.21 & -0.09 \\
\hline Existing home sales & 0.04 & 0.11 & $-0.59 * * *$ & -0.25 * & $0.37 * *$ & 0.41 ** & -0.23 & 0.07 & 0.14 & 0.34 & -0.15 & -0.09 \\
\hline FOMC interest rate decision & -0.03 & -0.05 & $-0.60 *$ & 0.03 & 0.26 & 0.21 * & $0.83 * \star \star$ & -0.10 & -0.18 & -0.15 & 0.00 & -0.07 \\
\hline Advance GDP & 0.02 & 0.07 & -0.11 & 0.33 & 0.15 & 0.21 & 0.86 & 0.10 & 0.23 * & $0.26 * \star \star$ & 0.07 & 0.20 \\
\hline Housing starts & 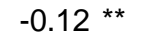 & -0.03 & 0.10 & -0.04 & -0.19 & -0.01 & -0.07 & 0.09 & 0.19 & -0.10 & -0.19 & -0.16 \\
\hline ISM manufacturing survey & -0.02 & 0.14 & -0.02 & 0.08 & 0.04 & 0.20 & $0.63 * \star *$ & -0.06 & -0.07 & -0.07 & $0.25 * \star$ & 0.13 \\
\hline PPI ex-food and energy & $-0.16 *$ & -0.01 & -0.14 & $-0.24 *$ & -0.13 & 0.02 & -0.64 & -0.08 & -0.10 & -0.13 & -0.04 & -0.08 \\
\hline ECB interest rate decision & -0.13 ** & -0.08 & -0.03 & 0.11 & 0.03 & 0.17 & 0.14 & 0.23 * & 0.02 & $0.21 * *$ & -0.04 & -0.05 \\
\hline German IFO survey & $0.17 \star \star \star *$ & 0.22 ** & $0.29 * *$ & 0.31 ** & -0.14 & -0.26 & 0.15 & 0.09 & 0.13 & 0.07 & 0.15 & 0.09 \\
\hline UK interest rate decision & 0.08 & $0.35 * * *$ & 0.18 * & $0.39 * * \star$ & -0.08 & 0.00 & $0.72 * \star *$ & $0.33 * \star *$ & 0.18 * & 0.17 * & -0.08 & -0.12 \\
\hline Lagged price t-1 & -0.04 * & -0.03 & -0.01 & $0.12 * \star \star$ & -0.02 & -0.03 & -0.03 * & 0.01 & 0.03 * & -0.03 & -0.08 * & -0.10 \\
\hline Lagged price t-2 & -0.02 & 0.03 & $-0.06 * \star \star$ & -0.02 & $-0.05 * \star \star$ & $-0.03 *$ & 0.00 & -0.02 & 0.00 & 0.02 & 0.00 & -0.03 \\
\hline U.S. dollar index change $t$ & $-1.04 * \star \star$ & $-1.13 * \star \star$ & $-0.74 * * \star$ & $-1.02 * \star *$ & $-0.63 * \star \star$ & $-0.67 * \star \star$ & $-0.52 * \star *$ & $-0.53 * \star *$ & $-0.42 * \star *$ & $-0.45 * * *$ & $-0.57 \star \star \star$ & $-0.41 * * *$ \\
\hline U.S. dollar index change t-1 & $-0.10 * \star$ & -0.04 & $-0.18 * \star$ & 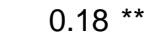 & -0.01 & -0.07 & 0.11 & -0.03 & -0.10 & $-0.14 * \star$ & -0.07 & $-0.25 * \star \star$ \\
\hline U.S. dollar index change t-2 & -0.04 & 0.04 & -0.03 & 0.18 ** & 0.02 & -0.04 & 0.01 & -0.09 & -0.05 & -0.08 & -0.01 & 0.01 \\
\hline
\end{tabular}

Source: Authors' estimates. 
Table A5. Commodity Price Sensitivity to Announcements, December 2001-May 2009

\begin{tabular}{|c|c|c|c|c|c|c|c|c|c|c|c|c|}
\hline & Gold & Silver & Platinum & Palladium & $\begin{array}{c}\text { Crude } \\
\text { Oil }\end{array}$ & $\begin{array}{l}\text { Heating } \\
\text { Oil }\end{array}$ & $\begin{array}{c}\text { Natural } \\
\text { Gas }\end{array}$ & Wheat & Corn & Soybeans & Copper & Aluminium \\
\hline \multicolumn{13}{|c|}{ Macroeconomic announcements } \\
\hline Advance retail sales & -0.18 & -0.10 & -0.15 & -0.12 & -0.31 & -0.25 & -0.26 & -0.21 & -0.03 & $-0.34 * \star *$ & 0.15 & 0.08 \\
\hline Change in non-farm payrolls & $-0.32 * \star$ & $-0.41 * \star$ & 0.06 & -0.11 & 0.16 & 0.23 & 0.29 & 0.33 * & 0.34 * & 0.08 & -0.11 & 0.09 \\
\hline Consumer confidence & -0.13 & -0.14 & $-0.20 *$ & $-0.37 * \star$ & 0.22 & 0.32 * & 0.61 * & -0.04 & -0.03 & 0.05 & 0.24 & 0.06 \\
\hline Consumer price index & 0.10 & 0.34 * & -0.01 & 0.19 & -0.09 & -0.11 & -0.26 & 0.20 & 0.14 & 0.13 & -0.07 & -0.17 \\
\hline Employment cost index & 0.01 & 0.46 & 0.51 * & 0.83 * & 0.24 & 0.47 & 0.50 & -0.07 & 0.22 & 0.44 * & -0.62 & 0.14 \\
\hline Existing home sales & 0.01 & -0.13 & 0.07 & 0.10 & -0.23 & $-0.44 * \star$ & -0.53 & -0.04 & -0.20 & 0.12 & 0.16 & 0.01 \\
\hline FOMC interest rate decision & 0.02 & 0.02 & -0.02 & 0.02 & $-0.22 * \star \star$ & 0.07 & 0.08 & & & & $-0.11 * * \star$ & $* * \quad-0.15 * * *$ \\
\hline Advance GDP & 0.00 & 0.27 & 0.16 & 0.51 * & -0.21 & 0.14 & 0.30 & -0.36 & -0.57 & $-0.81 * \star$ & -0.02 & 0.05 \\
\hline Housing starts & -0.06 & -0.19 & -0.03 & 0.22 & 0.02 & 0.00 & $-0.45 * \star$ & -0.15 & -0.16 & -0.23 & 0.15 & $0.25 * \star$ \\
\hline Industrial production & 0.00 & $-0.33 *$ & -0.03 & 0.29 & 0.25 & 0.27 & -0.13 & 0.13 & -0.12 & -0.05 & -0.06 & 0.21 \\
\hline ISM manufacturing survey & $-0.21 *$ & $-0.28 *$ & 0.01 & -0.03 & -0.17 & -0.11 & -0.11 & 0.39 & 0.27 & 0.23 & 0.27 & 0.08 \\
\hline PPI ex-food and energy & 0.09 & $0.25 * *$ & 0.04 & 0.10 & 0.21 & 0.14 & $-0.49 *$ & $-0.12 *$ & -0.10 & $-0.05 * * \star$ & 0.04 & 0.08 \\
\hline ECB interest rate decision & 0.01 & 0.01 & -0.36 & -0.33 & 0.18 & -0.11 & -0.29 & -0.31 & $0.07 * *$ & $-0.50 * *$ & $-0.55 * \star \star$ & $* * \quad-0.19 * *$ \\
\hline German IFO survey & 0.12 & 0.03 & $0.29 * *$ & 0.05 & $0.50 * \star$ & 0.40 * & $1.00 * * *$ & 0.25 & 0.30 & 0.28 & 0.25 & 0.28 * \\
\hline UK interest rate decision & 0.14 & 0.32 & -0.04 & 0.26 & -0.21 & -0.04 & 0.32 & 0.01 & 0.18 ** & 0.02 ** & 0.10 & 0.19 * \\
\hline \multicolumn{13}{|l|}{ Lagged by one day } \\
\hline Change in non-farm payrolls & -0.08 & -0.03 & $-0.29 \star \star$ & $-0.56 \star \star \star$ & 0.02 & 0.09 & 0.09 & 0.19 & 0.38 ** & $0.32 * \star$ & 0.16 & $0.27 \star \star$ \\
\hline Existing home sales & 0.09 & 0.24 & $-0.38 * * *$ & -0.16 & 0.15 & 0.35 & -0.27 & 0.53 & 0.43 & $0.62 * \star \star$ & $-0.33 * \star *$ & $* * \quad-0.20 * *$ \\
\hline FOMC interest rate decision & $-0.23 * * *$ & $-0.40 * \star \star$ & $-0.10 *$ & -0.03 & 0.42 & 0.18 & 0.68 ** & -0.16 & -0.29 * & -0.08 & 0.13 & -0.18 \\
\hline Advance GDP & -0.20 & -0.11 & -0.22 & 0.19 & 0.37 & 0.65 & 0.71 & 0.06 & 0.10 & 0.17 * & 0.05 & 0.08 \\
\hline ISM manufacturing survey & 0.02 & 0.26 & -0.02 & 0.27 & 0.09 & 0.34 & $0.79 * * *$ & -0.07 & -0.03 & 0.00 & 0.30 * & 0.15 \\
\hline PPI ex-food and energy & $-0.21 *$ & -0.04 & -0.07 & $-0.32 * *$ & -0.13 & 0.04 & -0.90 & -0.06 & -0.08 & -0.03 & 0.01 & -0.11 \\
\hline ECB interest rate decision & $-0.32 * *$ & -0.28 & $-0.47 * *$ & -0.11 & -0.15 & -0.22 & 0.37 & 0.01 & -0.04 & $0.27 * * *$ & 0.19 & 0.33 * \\
\hline German IFO survey & 0.21 ** & $0.35 * * *$ & 0.28 ** & $0.40 * * *$ & -0.25 & -0.17 & 0.28 & $-0.39 * * *$ & 0.22 & 0.00 & 0.26 * & 0.18 \\
\hline UK interest rate decision & -0.01 & 0.29 * & 0.00 & 0.31 ** & -0.22 & -0.19 & 0.75 * & 0.22 & 0.12 & -0.01 & 0.20 & 0.09 \\
\hline Lagged price t-1 & -0.03 & 0.01 & 0.01 & $0.11 * \star \star$ & -0.04 * & $-0.05 * *$ & -0.01 & -0.01 & 0.05 * & -0.01 & $-0.06 * * \star$ & $-0.08 * * *$ \\
\hline Lagged price $\mathrm{t}-2$ & -0.01 & 0.03 & -0.03 & -0.02 & -0.02 & 0.00 & 0.01 & 0.01 & 0.01 & 0.01 & -0.01 & -0.04 \\
\hline
\end{tabular}

Source: Authors' estimates. 
Table A6. Commodity Price Sensitivity to Announcements (with U.S. dollar control), December 2001-May 2009

\begin{tabular}{|c|c|c|c|c|c|c|c|c|c|c|c|c|}
\hline & Gold & Silver & Platinum & Palladium & $\begin{array}{c}\text { Crude } \\
\text { Oil }\end{array}$ & $\begin{array}{l}\text { Heating } \\
\text { Oil }\end{array}$ & $\begin{array}{c}\text { Natural } \\
\text { Gas }\end{array}$ & Wheat & Corn & Soybeans & Copper & Aluminium \\
\hline \multicolumn{13}{|c|}{ Macroeconomic announcements } \\
\hline Advance retail sales & -0.07 & 0.02 & -0.04 & 0.09 & -0.20 & -0.08 & -0.10 & -0.15 & 0.01 & -0.28 ** & 0.23 & 0.10 \\
\hline Change in non-farm payrolls & -0.09 & -0.16 & 0.21 * & 0.13 & 0.42 & $0.50 *$ & 0.49 & $0.45 * *$ & $0.42 * \star \star$ & 0.13 & 0.04 & 0.22 * \\
\hline Consumer confidence & -0.07 & 0.03 & -0.16 & $-0.32 * *$ & 0.30 * & $0.40 * *$ & 0.65 * & -0.01 & 0.00 & 0.07 & 0.25 & 0.10 \\
\hline Consumer price index & 0.06 & 0.34 * & 0.01 & 0.14 & -0.11 & -0.13 & -0.26 & 0.20 & 0.18 & 0.15 & -0.04 & -0.12 \\
\hline Employment cost index & -0.12 & 0.20 & 0.33 & 0.68 & 0.05 & 0.28 & 0.44 & -0.17 & 0.12 & 0.34 & -0.72 * & 0.03 \\
\hline Existing home sales & 0.07 & -0.03 & 0.10 & 0.14 & -0.18 & $-0.43 * *$ & -0.56 & -0.03 & -0.18 & 0.13 & 0.20 & 0.02 \\
\hline FOMC interest rate decision & $0.03 * * *$ & 0.01 & -0.02 * & 0.05 & 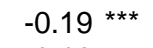 & 0.09 & 0.10 & & & & -0.12 * & -0.13 ** \\
\hline Advance GDP & -0.04 & 0.30 & 0.20 & $0.61 *$ & -0.18 & 0.19 & 0.40 & -0.35 & -0.55 & $-0.79 * *$ & -0.09 & 0.01 \\
\hline Housing starts & -0.04 & -0.18 & -0.01 & 0.20 & 0.05 & 0.02 & $-0.46 * *$ & -0.16 & -0.16 & -0.21 & 0.15 & 0.26 ** \\
\hline Industrial production & 0.01 & -0.27 & 0.04 & 0.34 & 0.31 & 0.31 & -0.08 & 0.14 & -0.10 & -0.03 & -0.02 & 0.21 \\
\hline ISM manufacturing survey & -0.03 & 0.01 & 0.13 & 0.13 & -0.06 & -0.01 & -0.06 & 0.47 & 0.35 & 0.29 & 0.38 * & 0.16 \\
\hline PPI ex-food and energy & 0.00 & 0.15 & -0.02 & 0.05 & 0.19 & 0.12 & -0.48 * & -0.14 & -0.13 & $-0.09 * * *$ & -0.01 & 0.03 \\
\hline ECB interest rate decision & -0.08 & -0.12 & -0.41 & -0.28 & 0.19 & -0.08 & -0.21 & -0.21 & -0.08 * & $-0.45 * \star$ & $-0.62 * \star *$ & * -0.25 ** \\
\hline German IFO survey & 0.00 & -0.04 & 0.21 * & 0.00 & 0.37 * & 0.27 & $0.88 * \star$ & 0.18 & 0.25 & 0.26 & 0.18 & 0.27 ** \\
\hline UK interest rate decision & 0.07 & 0.19 & -0.08 & 0.18 & -0.22 & -0.08 & 0.27 & 0.00 & $0.17 * * *$ & $0.00 * \star$ & 0.04 & 0.14 \\
\hline \multicolumn{13}{|l|}{ Lagged by one day } \\
\hline Change in non-farm payrolls & -0.07 & 0.02 & $-0.25 * \star$ & $-0.53 \star \star$ & 0.01 & 0.09 & 0.12 & 0.22 & $0.40 * \star \star$ & $0.34 * \star$ & 0.19 & 0.30 ** \\
\hline Existing home sales & 0.08 & 0.23 & $-0.36 * * *$ & -0.11 & 0.19 & 0.35 & -0.24 & 0.47 & 0.34 & 0.54 ** & $-0.33 * * *$ & $* \quad-0.21 * *$ \\
\hline FOMC interest rate decision & 0.01 & -0.13 * & 0.04 * & 0.19 & 0.53 & 0.33 ** & 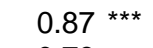 & -0.13 & -0.27 * & -0.05 & 0.21 & -0.11 \\
\hline Advance GDP & -0.09 & 0.04 & -0.10 & 0.28 & 0.40 & 0.69 & 0.79 & 0.22 & 0.21 & $0.27 * \star \star$ & 0.10 & 0.16 \\
\hline Housing starts & $-0.14 * \star \star$ & -0.01 & 0.03 & -0.12 & -0.33 & -0.13 & -0.18 & -0.19 & -0.03 & -0.33 & -0.18 & -0.10 \\
\hline ISM manufacturing survey & 0.00 & 0.15 & -0.05 & 0.15 & 0.07 & 0.31 & $0.75 * \star \star$ & -0.08 & -0.03 & 0.00 & 0.27 & 0.11 \\
\hline PPI ex-food and energy & -0.16 & 0.00 & -0.04 & $-0.29 *$ & -0.10 & 0.05 & -0.87 & -0.09 & -0.08 & -0.04 & 0.00 & -0.10 \\
\hline ECB interest rate decision & $-0.32 * *$ & -0.26 & $-0.48 * *$ & -0.19 & -0.18 & -0.35 & 0.22 & 0.01 & -0.06 & 0.27 ** & 0.21 & 0.32 \\
\hline German IFO survey & 0.15 * & 0.32 ** & 0.23 * & 0.36 ** & -0.26 & -0.19 & 0.28 & $-0.45^{\star \star \star *}$ & 0.15 & -0.06 & 0.21 & 0.17 \\
\hline UK interest rate decision & -0.03 & $0.22 *$ & 0.00 & 0.32 * & -0.25 & -0.22 & 0.76 ** & 0.22 & 0.11 & -0.01 & 0.19 & 0.05 \\
\hline Lagged price t-1 & $-0.09 * \star \star$ & -0.01 & -0.01 & 0.11 *** & $-0.06 * \star \star$ & 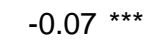 & -0.02 & -0.02 & 0.04 & -0.01 & $-0.07 * \star \star$ & ** $-0.10 * \star \star$ \\
\hline Lagged price t-2 & -0.02 & 0.03 & -0.02 & -0.01 & -0.02 & -0.01 & 0.01 & 0.01 & 0.00 & 0.01 & -0.01 & $-0.05 * \star$ \\
\hline U.S. dollar index change t & $-1.23 * * \star$ & $-1.52 * * \star$ & $-0.82 * * *$ & $-1.15 * * *$ & $-0.88 * * *$ & $-0.94 * * *$ & $-0.64 * \star \star$ & $-0.65 * * *$ & $-0.52 * * \star$ & $-0.57 * \star \star$ & $-0.70 * * *$ & $* * \quad-0.51 * * \star$ \\
\hline U.S. dollar index change t-1 & $-0.20 * \star \star$ & -0.10 & $-0.13 * *$ & 0.16 & -0.06 & -0.09 & 0.11 & 0.05 & -0.12 & -0.12 & -0.04 & $-0.23 * \star \star$ \\
\hline U.S. dollar index change t-2 & -0.01 & 0.09 & 0.09 & 0.17 & 0.16 & 0.09 & -0.05 & -0.10 & -0.08 & -0.03 & 0.03 & -0.03 \\
\hline
\end{tabular}

Source: Authors' estimates. 
Table A6. Commodity Price Sensitivity to Announcements-High/ Low Volatility and Good/Bad News Models, Jan 1997-May 2009 1/

\begin{tabular}{|c|c|c|c|c|c|c|c|c|c|c|c|c|}
\hline & Gold & Silver & Platinum & Palladium & $\begin{array}{c}\text { Crude } \\
\text { Oil }\end{array}$ & $\begin{array}{l}\text { Heating } \\
\text { Oil }\end{array}$ & $\begin{array}{l}\text { Natural } \\
\text { Gas }\end{array}$ & Wheat & Corn & Soybeans & Copper & Aluminium \\
\hline Aggregate news t & $-0.08 * * *$ & -0.02 & -0.01 & 0.06 & 0.01 & -0.02 & -0.11 & 0.01 & -0.02 & 0.00 & 0.02 & 0.05 \\
\hline Aggregate news t- 1 & -0.03 & 0.01 & -0.04 & 0.03 & -0.04 & 0.06 & 0.03 & -0.02 & 0.00 & -0.01 & -0.03 & 0.00 \\
\hline Aggregate news t-2 & 0.02 & 0.04 & 0.05 & -0.03 & -0.05 & -0.05 & 0.10 & 0.06 & -0.02 & -0.01 & 0.07 * & 0.05 \\
\hline Aggregate news t & -0.06 & 0.02 & 0.04 & 0.14 * & 0.04 & 0.01 & -0.13 & 0.04 & -0.02 & 0.01 & 0.05 & 0.08 \\
\hline Aggregate news t-1 & -0.05 & 0.02 & -0.06 & 0.02 & -0.05 & 0.10 & 0.04 & -0.01 & 0.00 & -0.01 & -0.04 & 0.01 \\
\hline Aggregate news $\mathrm{t}-2$ & 0.06 * & 0.08 & 0.07 & -0.02 & -0.06 & -0.06 & 0.14 & 0.10 & -0.02 & 0.00 & 0.09 * & 0.07 \\
\hline \multicolumn{13}{|c|}{$\begin{array}{l}\text { Model } 3 \text { - Good/ bad news with no US\$ control } \\
\text { Aggregate news regressor }\end{array}$} \\
\hline Good news $\mathrm{t}$ & -0.02 & 0.02 & -0.02 & 0.12 & -0.05 & -0.02 & -0.07 & 0.09 & 0.10 * & 0.10 * & 0.09 & 0.12 *** \\
\hline Good news t-1 & -0.03 & -0.05 & -0.04 & 0.04 & -0.09 & 0.04 & -0.05 & -0.04 & $-0.08 *$ & 0.02 & 0.01 & -0.07 \\
\hline Bad news t & $-0.17 * * \star$ & -0.07 & 0.02 & -0.01 & 0.08 & -0.02 & -0.15 & -0.08 & $-0.20 * * *$ & $-0.13 * *$ & -0.05 & -0.04 \\
\hline Bad news t-1 & -0.03 & 0.08 & -0.05 & 0.01 & 0.01 & 0.08 & 0.15 & 0.02 & 0.11 & -0.03 & -0.06 & 0.08 \\
\hline \multicolumn{13}{|c|}{$\begin{array}{l}\text { Model } 3 \text { - Good/ bad news with US\$ control } \\
\text { Aggregate news regressor }\end{array}$} \\
\hline Good news $t$ & 0.01 & 0.04 & 0.00 & 0.15 * & -0.03 & 0.00 & -0.05 & 0.10 & 0.11 ** & 0.11 ** & 0.10 * & 0.13 *** \\
\hline Good news t-1 & -0.04 & -0.05 & -0.04 & 0.04 & -0.08 & 0.05 & -0.06 & -0.03 & -0.08 & 0.02 & 0.01 & -0.06 \\
\hline Bad news t & -0.11 * & -0.02 & 0.05 & 0.05 & 0.11 & 0.01 & -0.14 & -0.07 & $-0.19 * \star \star$ & -0.12 * & -0.03 & -0.02 \\
\hline Bad news t-1 & -0.03 & 0.09 & -0.05 & -0.02 & 0.02 & 0.09 & 0.15 & 0.03 & 0.11 & -0.02 & -0.06 & 0.09 * \\
\hline \multicolumn{13}{|c|}{$\begin{array}{l}\text { Model } 1 \text { - High/ low volatility with no US\$ control } \\
\text { Regressors }\end{array}$} \\
\hline Hi vol - news t & -0.07 & -0.05 & 0.07 & 0.11 & -0.01 & 0.06 & 0.01 & -0.16 & -0.19 & -0.16 & -0.04 & 0.04 \\
\hline Hi vol - news t-1 & -0.07 & 0.02 & -0.13 & 0.11 & -0.20 & -0.04 & 0.00 & -0.07 & -0.16 & -0.07 & 0.01 & -0.06 \\
\hline Lo vol - news t & $-0.09 * \star \star$ & -0.02 & -0.02 & 0.04 & 0.02 & -0.06 & -0.14 & 0.06 & 0.01 & 0.02 & 0.03 & 0.05 \\
\hline Lo vol - news t-1 & -0.02 & 0.01 & -0.02 & 0.01 & 0.00 & 0.11 & 0.06 & 0.00 & 0.04 & 0.01 & -0.03 & 0.01 \\
\hline \multicolumn{13}{|c|}{$\begin{array}{l}\text { Model } 2 \text { - High/ low volatility with US\$ control } \\
\text { Regressors }\end{array}$} \\
\hline Hi vol - news t & -0.03 & -0.04 & 0.08 & 0.15 & 0.02 & 0.08 & 0.03 & -0.15 & -0.18 & -0.15 & -0.01 & 0.05 \\
\hline Hi vol - news t-1 & -0.11 * & -0.01 & -0.11 & 0.11 & -0.20 & -0.04 & 0.00 & -0.06 & -0.16 & -0.08 & 0.01 & -0.05 \\
\hline Lo vol - news t & -0.04 & 0.02 & 0.02 & 0.08 & 0.04 & -0.03 & -0.13 & 0.08 & 0.02 & 0.03 & 0.04 & 0.06 \\
\hline Lo vol - news t-1 & -0.02 & 0.02 & -0.03 & -0.01 & 0.01 & 0.12 & 0.05 & 0.01 & 0.04 & 0.01 & -0.04 & 0.02 \\
\hline
\end{tabular}

Source: Authors' estimates. 
Figure A1. Sample Autocorrelation Functions for the Squared Residuals from an AR(1) equation of log returns, 1997-2009 1/
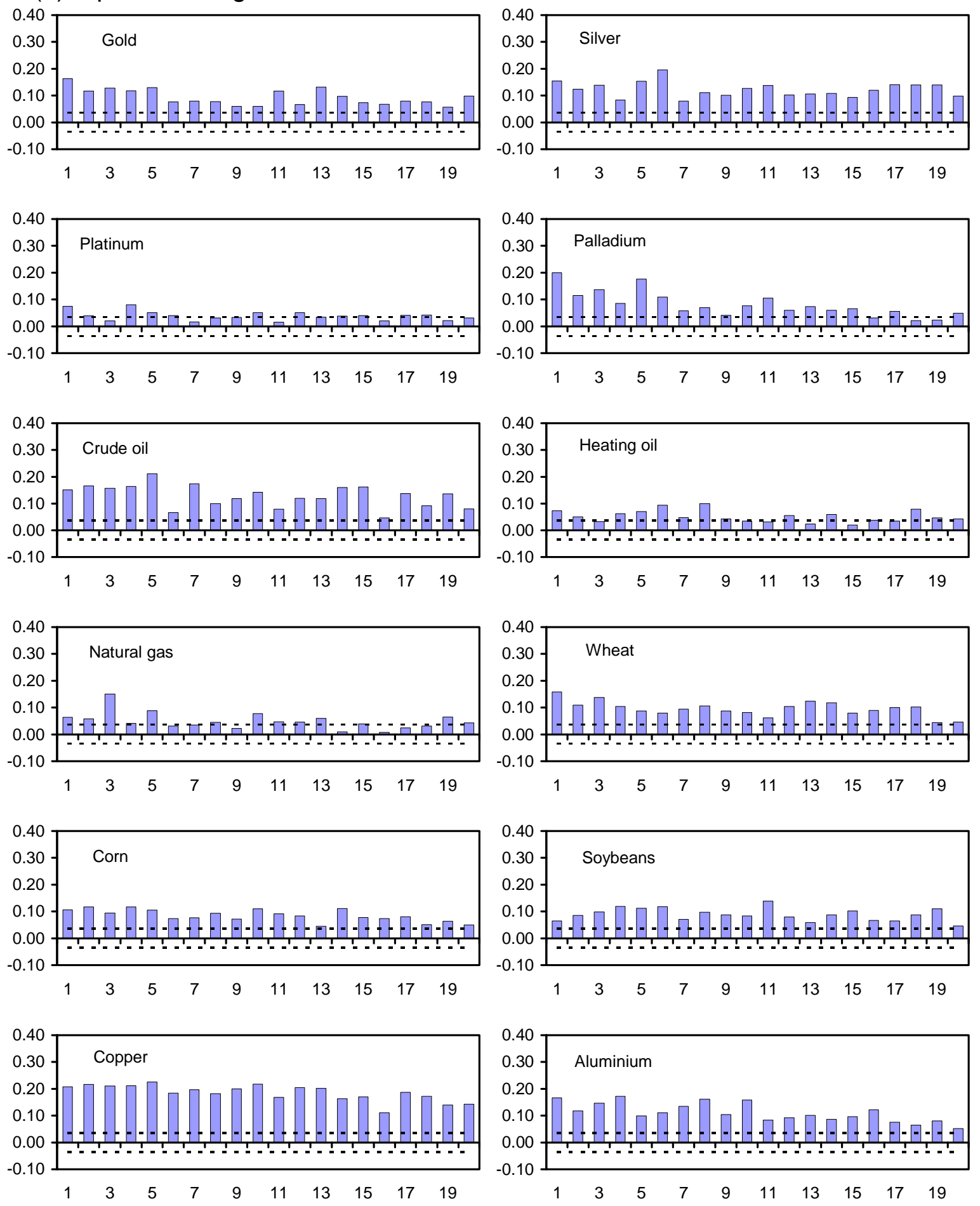

Source: Authors' calculations.

1/ Dashed lines represent the 95 percent confidence intervals. 
Figure A2. Sample Partial Autocorrelation Functions for the Squared Residuals from an AR(1) equation of log returns, 1997-2009 1/
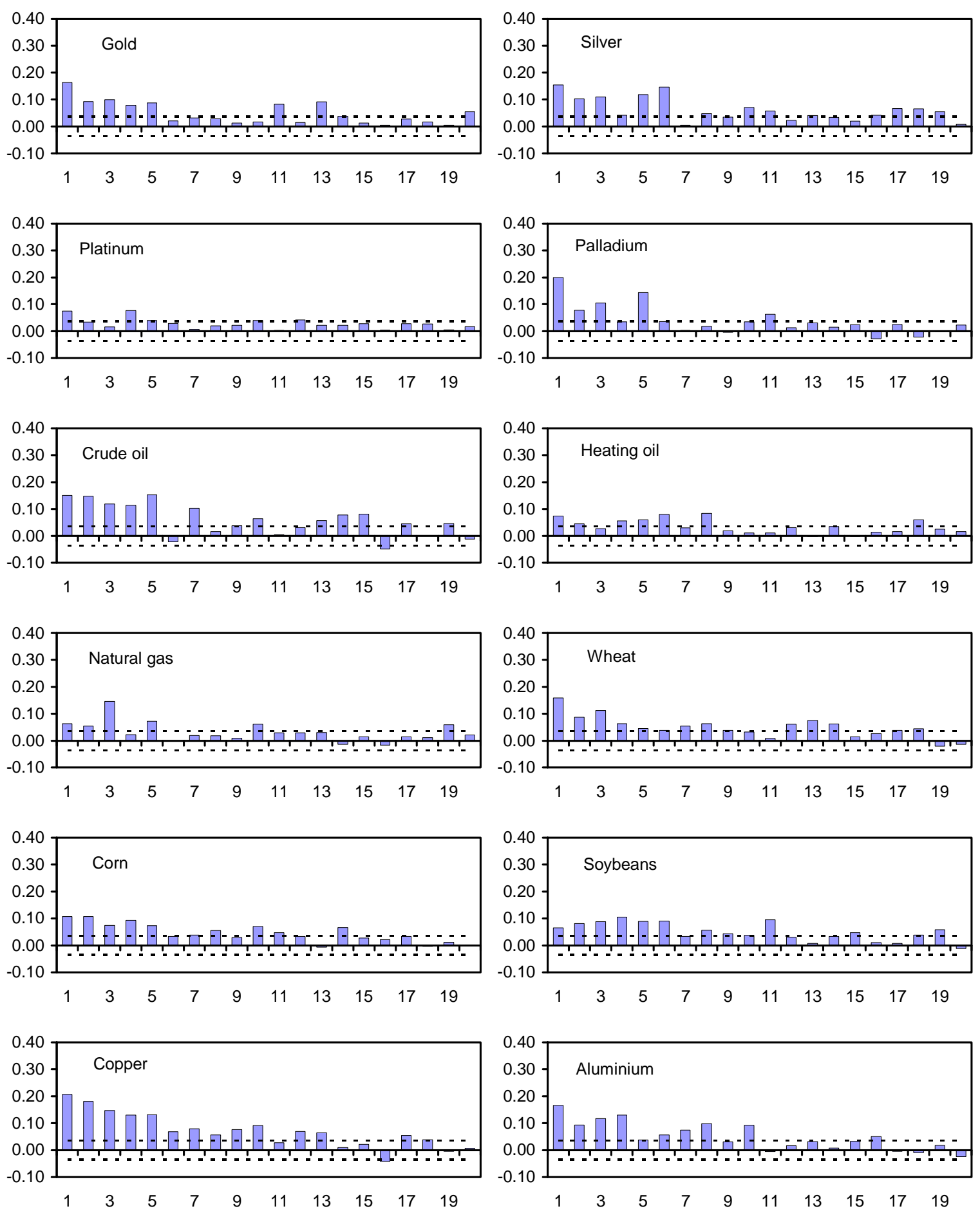

Source: Authors' calculations.

1/ Dashed lines represent the 95 percent confidence intervals. 